\title{
Representatives of the family Actinostromatidae (Stromatoporoidea) in the Devonian of southern Poland and their ecological significance
}

\author{
Paweł Wolniewicz \\ Institute of Geology, Adam Mickiewicz University, Bogumiła Krygowskiego 12, 61-680 Poznań, Poland; \\ pawelw@amu.edu.pl
}

\begin{abstract}
Stromatoporoids of the family Actinostromatidae are common constituents of Givetian to Frasnian (Devonian) organic buildups. The species-level structure of actinostromatid assemblages from the Devonian of southern Poland is described in the present paper, with special emphasis on ecological factors that influenced species composition of the communities. Nine species of the genera Actinostroma and Bifariostroma are distinguished. Members of the family Actinostromatidae predominated in stromatoporoid assemblages within lower Frasnian carbonate buildup margins. The most diverse actinostromatid faunas were found within the middle Givetian Stringocephalus Bank, in the upper Givetian-lower Frasnian biostromal complex and in the lower Frasnian organic buildups. Species-level biodiversity was lowest within detrital facies which surrounded the Frasnian carbonate buildups. Species of Actinostroma with well-developed colliculi are commonest within the middle Givetian to early Frasnian coral-stromatoporoid biostromal complexes, whereas species with strongly reduced colliculi predominate early-middle Frasnian organic buildups. The skeletal structure of actinostromatids reflects environmental changes, documenting a transition from species with thin, close-set pillars and widely spaced laminae (common in the middle Givetian) to those with long, thick pillars and megapillars (in Bifariostroma), which were predominant during the early and middle Frasnian. The distribution of growth forms among species reveals a significant intraspecific variation. Species of Actinostroma can be either tabular or low domical, depending on the palaeoenvironmental setting. Thus, the present study confirms that stromatoporoid morphology was influenced by environmental conditions.
\end{abstract}

Keywords: central Europe, sponges, palaeoecology, palaeoenvironmental variation, intraskeletal variation

\section{Introduction}

Stromatoporoid sponges of the family Actinostromatidae Nicholson, $1886 \mathrm{~b}$ are common frame builders in Givetian to Frasnian (Devonian) organic buildups. They represent a substantial part of widely distributed massive stromatoporoid communities in shallow and turbulent waters several metres below the sea water level (Racki \& Sobstel, 2004). Amongst the genera that belong to this family, Actinostroma Nicholson, $1886 \mathrm{~b}$ is commonest in the Devonian. Rich Actinostroma assemblages were described, amongst others, from the Devonian of the Holy Cross Mountains in southern Poland
(Kaźmierczak, 1971; Racki, 1993; Racki \& Sobstel, 2004).

The palaeoecology and sedimentology of stromatoporoid communities from the Givetian and Frasnian have also been investigated (Da Silva et al., 2011a, b), but most studies have been limited to the generic level, which is considered to be more robust taxonomically speaking. The aim of the present paper is to describe the structure of actinostromatid assemblages from the Devonian of southern Poland at the species level, with special emphasis on ecological factors that influenced the species composition of communities of Actinostroma and Bifariostroma Khalfina, 1968. 
The relation of Devonian actinostromatids to palaeoenvironmental conditions has been barely studied at the species level. Cockbain (1984) included A. papillosum (Bargatzky, 1881) and A. windjanicum Cockbain, 1984 in his list of stromatoporoid species that were abundant along the platform margin of Givetian-Frasnian carbonate complexes of the Canning Basin (Australia). The palaeoecology of those species was also studied by Wood (2000). Cook (1999) had earlier described Actinostroma filitextum Lecompte, 1951 from the Festromatopora heideckeri-Amphipora ramosa-Stringocephalus community, which dominates the biostromal complex in the Givetian of the Fanning River Group (Australia).

\section{Geological setting}

Rich Actinostroma assemblages occur in Devonian (Givetian to Frasnian) carbonates of the Holy Cross Mountains, of Upper Silesia and in the Kraków area in central and southern Poland, that formed along the southwestern margin of Laurussia (Fig. 1; Pisarzowska et al., 2006). Stromatoporoids are commonest in the western part of the Kielce

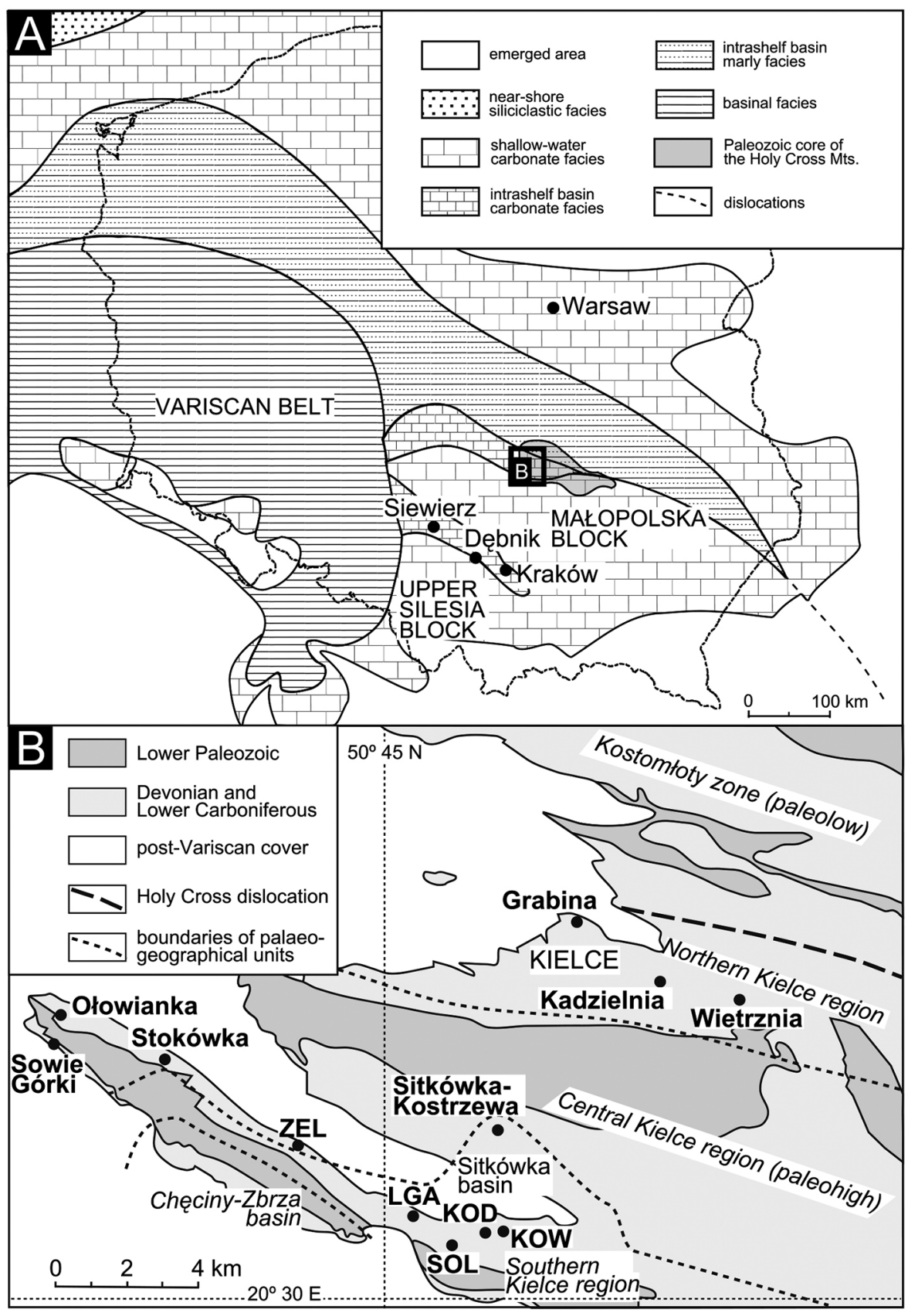

Fig. 1. Localities studied: A - sections beyond the Holy Cross Mountains, shown within the palaeogeographical framework of the Givetian to Frasnian in Poland (modified after Racki, 1993 and Pisarzowska et al., 2006); B - structural framework of the western part of the Kielce region and palaeogeography of the western Holy Cross Mountains near the Givetian-Frasnian boundary, with localities (modified after Racki, 1993). For locality abbreviations, reference is made to the text. 
region (southern part of the Palaeozoic core of the Holy Cross Mountains), which is further subdivided into four subregions: Northern, Central, Southern and the Chęciny-Zbrza area (Racki, 1993). Here, actinostromatids occur both in carbonates assigned to the Kowala Formation and in overlying detrital limestones developed as fore-reef facies (Narkiewicz et al., 1990).

The evolution of the Holy Cross Mountains during the Givetian and Frasnian was studied in detail by Racki (1993) and Szulczewski (1995). Four deepening pulses contributed to the rise and demise of stromatoporoid-coral assemblages. During the middle Givetian, the undifferentiated Stringocephalus Bank (Stringocephalus Beds; Fig. 2) was drowned and replaced by a coral-stromatoporoid biostromal complex, the so-called Lower Sitkówka Beds. During a transgressive pulse in the early Frasnian organic buildups (Upper Sitkówka Beds), flanked by fore-reef slopes (mud mounds of the Kadzielnia Limestone Member), detrital facies (Detrital Beds) and deeper facies of the Kostomłoty Zone, formed. The central part of the Kielce region constituted an elevated part of the structure, while the Northern and Southern subregions represented the fore-reef and back-reef slopes. A transgressive pulse during Palmatolepis rhenana conodont Zone time saw the end to carbonate sedimentation in the area (Racki, 1993).

Actinostromatids occur in the Stringocephalus Beds within wackestones and floatstones of a biostromal unit that forms the middle part of the succession (Fig. 3A), which is presumably middle Givetian in age (Sobstel, 2003). The parautochthonous, diverse stromatoporoid-coral assemblages represent low-relief organic buildups that originated within shelf lagoons with open-marine influences which were most distinct in the Siewierz area of northeastern Upper Silesia (Racki, 1993).

The upper Givetian Lower Sitkówka Beds contain massive stromatoporoid assemblages (Kaźmierczak, 1971), formed by colonisation of a muddy bottom, in shallow water (about 2 to 13 m depth; Racki, 1993), with small non-rigid stromatoporoid buildups and biostromes surrounding depression areas. The Miedzianka elevation (Kowalczewski, 1963), located in the Southern Kielce subregion, was surrounded by deeper depositional basins: the Chęciny intershoal area and stagnant Sitkówka depression, formed near the GivetianFrasnian boundary (Fig. 1B; Racki, 1993). Massive stromatoporoids were absent from depression areas, but fine skeletal debris was washed off an adjacent biostromal fringe during storms and admixed with deeper-water communities, characterised by the presence of numerous rugose corals (Disphyllum; Fig. 3B).

During the early Frasnian a symmetrical organic buildup emerged in the Kielce area. The Central Kielce subregion represents the shoal, flanked on the north and south by slopes recognised in the Northern and Southern Kielce subregions (Racki, 1993; Krawczyński, 2002). A massive detrital facies (Fig. $3 \mathrm{C})$, with redeposited and abraded stromatoporo-

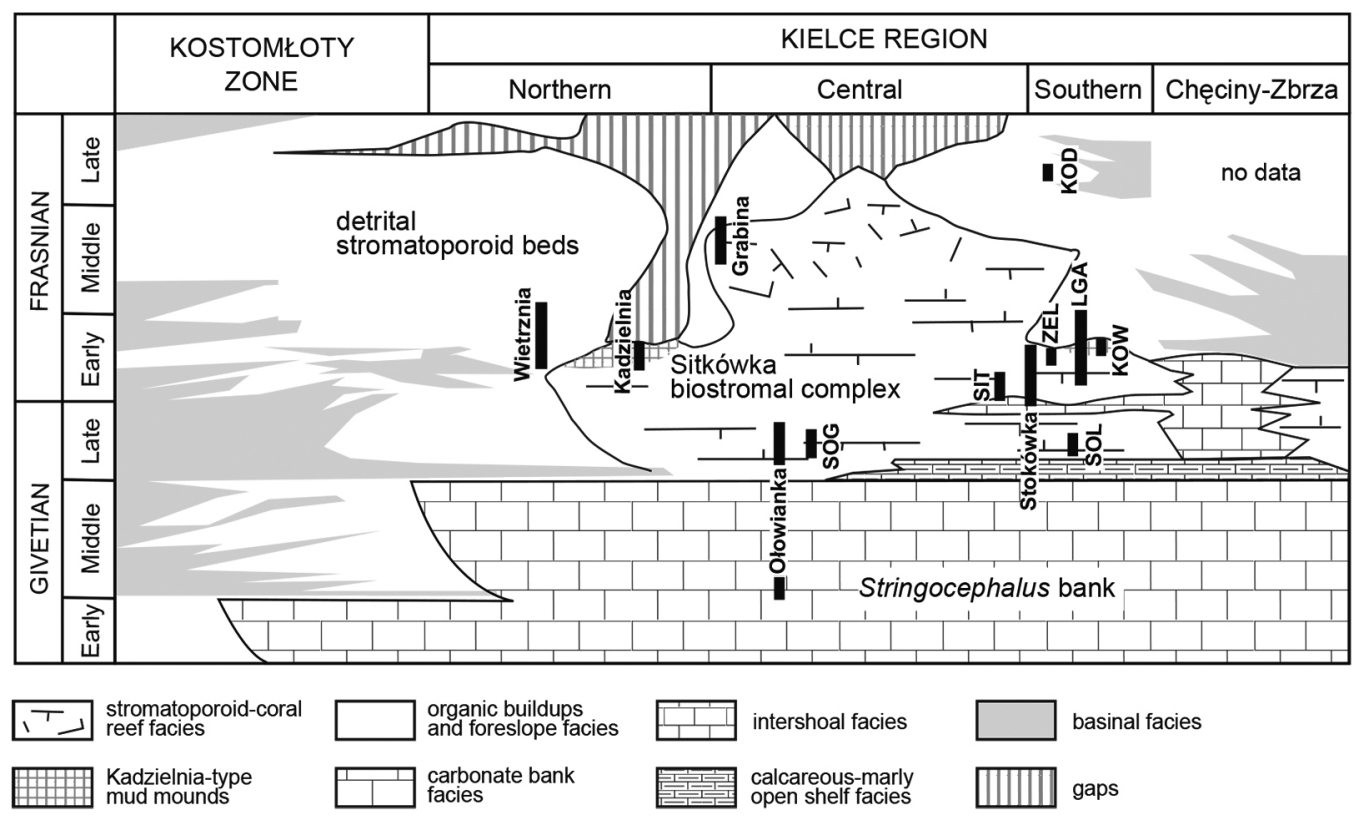

Fig. 2. Stratigraphical/facies cross section of the Givetian to Frasnian in the western part of the Kielce region (modified after Racki, 1993 and Pisarzowska et al., 2006), with localities studied. 

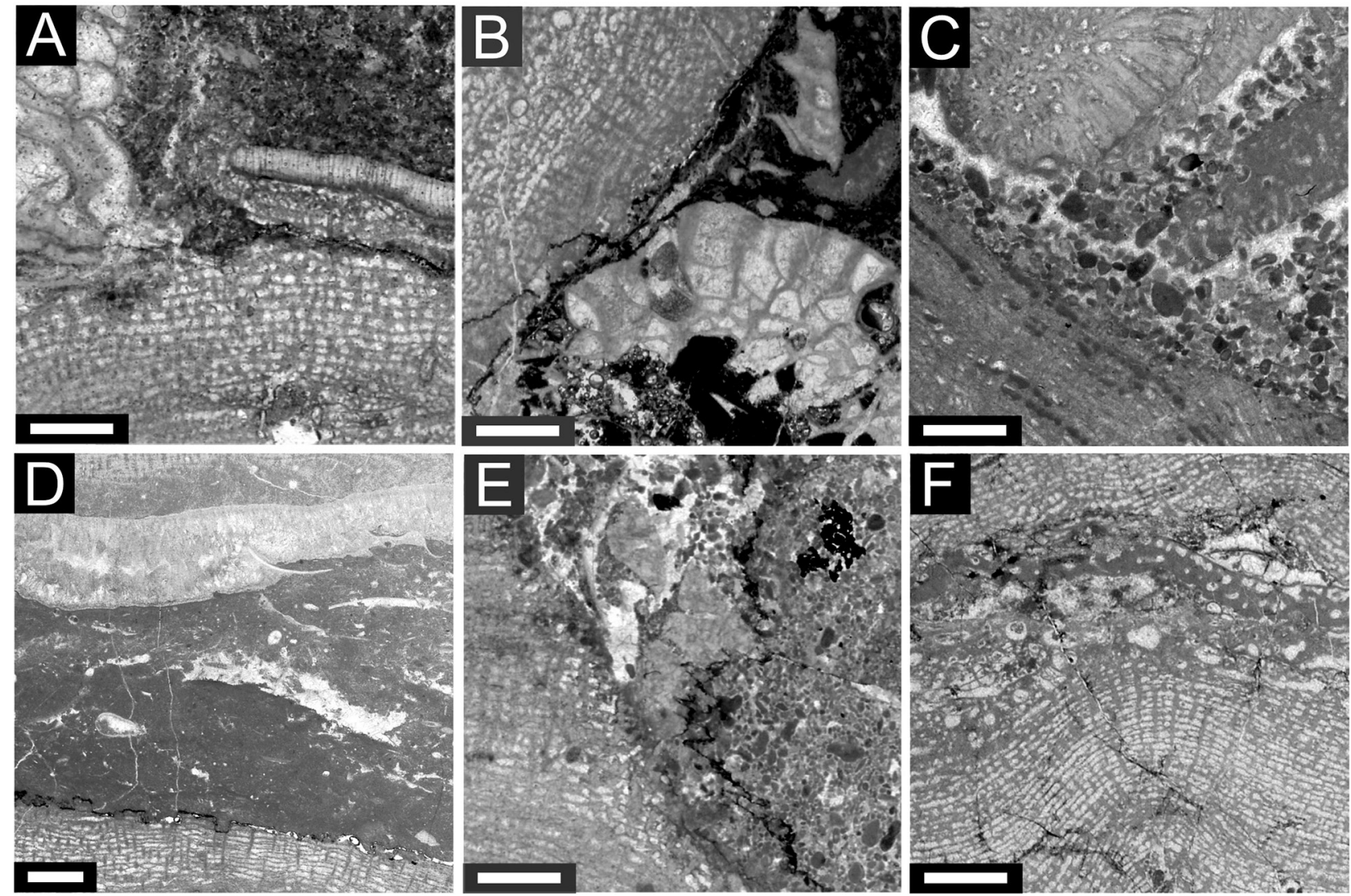

Fig. 3. Main microfacies of Givetian to Frasnian coral-stromatoporoid assemblages of the Holy Cross Mountains and adjacent areas. Scale bars equal $2 \mathrm{~mm}$ : A - middle Givetian Stringocephalus Beds: Actinostroma densatum Lecompte, 1951 in floatstones of the biostromal unit at Siewierz-Dziewki, set C (specimen UAM-DZI 1); B - upper Givetian/ lower Frasnian of the Chęciny intershoal area and the stagnant Sitkówka depression: Actinostroma expansum (Hall and Whitfield, 1873) and rugose corals in wackestones at Stokówka (specimen UAM-STO 74); C - grainstones of the Stromatoporoid Detrital Beds, which flanked the early-middle Frasnian organic buildup (specimen UAM-GRA 4); D - laminar and tabular stromatoporoids: Actinostroma sp. in the lower part and Stachyodes australe (Wray, 1967) in the upper part of the photograph; Kadzielnia Limestone Member (lower Frasnian; specimen UAM-KDZ 3); E Actinostroma cf. A. crassepilatum Lecompte, 1951 from the Wietrznia Beds, deposited between fore-reef and basinal environments on the slopes of the carbonate buildup (middle Frasnian; specimen UAM-WIE 3); F - Actinostroma expansum (Hall and Whitfield, 1873) overgrown by other stromatoporoids, including another conspecific individual, upper Givetian (specimen UAM-DEB 30)

ids, formed in the marginal belt of the shoal, in shallow (up to $10 \mathrm{~m}$ depth), agitated waters (Racki, 1993). The distinction between buildup (reef) facies and the surrounding detrital facies (Stromatoporoid Detrital Beds) is not always clear, because the stromatoporoid framestones are preserved only in exceptional cases (Szulczewski, 1971). On the northern and southern flanks of the buildup, in the subturbulent zone, mud mounds with rich tabular stromatoporoid faunas (Kaźmierczak, 1971) formed during the earliest Frasnian (the Kadzielnia Limestone Member; Fig. 3D). The Frasnian Wietrznia Beds were deposited in between fore-reef and basinal environments on the northern slope of the buildup (Racki \& Sobstel, 2004; see Fig. 3E).

The systematics of actinostromatids from the Holy Cross Mountains were studied by
Kaźmierczak (1971), while a single specimen was described by Racki \& Sobstel (2004).

\section{Material and methods}

A total of 94 stromatoporoids from central Poland, most of them collected by myself, were used in the present study. Specimens studied are part of a larger collection of Devonian stromatoporoids from Poland, which comprises 284 specimens of massive stromatoporoids and 601 thin sections. Stromatoporoids were recovered from 16 sections, 14 of which are located in the Kielce region of the Holy Cross Mountains. Members of the family Actinostromatidae were found at14 localities (Figs. 1B, 2). Localities are listed in an Appendix. For detailed 
Table 1. Skeletal features of actinostromatid stromatoporoids measured in the present study. All measurements were made using Strommetric image analysis software. All features, with the exception of pillar diameter, have been assessed in longitudinal thin sections. For details of measuring procedures, reference is made to Wolniewicz (2010).

\begin{tabular}{ll}
\hline \multicolumn{1}{c}{ Feature } & \multicolumn{1}{c}{ Measuring procedure } \\
number of laminae $2 \mathrm{~mm}$ & $\begin{array}{l}\text { counts are made along vertical } \\
\text { lines, downwards, beginning from } \\
\text { the upper boundaries of laminae; } \\
\text { a value of 0.5 is added if the last } \\
\text { laminae is partly included }\end{array}$ \\
thickness of laminae & $\begin{array}{l}\text { measured along vertical line; parts } \\
\text { of laminae adjacent to pillars not } \\
\text { measured }\end{array}$ \\
pillar width & $\begin{array}{l}\text { the distance between the topmost } \\
\text { and bottommost edges of a pillar, } \\
\text { measured along a vertical line }\end{array}$ \\
number of pillars & $\begin{array}{l}\text { counts made along horizontal } \\
\text { per } 2 \text { mm }\end{array}$ \\
& $\begin{array}{l}\text { lines, from left to right, beginning } \\
\text { a value of } 0.5 \text { is added if the last } \\
\text { pillar is partly included } \\
\text { diameter of the circle circum- } \\
\text { scribed around a tangential section } \\
\text { of the pillar }\end{array}$ \\
\hline
\end{tabular}

descriptions of sections studied, reference is made to Racki (1993).

A total number of 163 thin sections from all specimens of Actinostroma and Bifariostroma were made. Five features of pillars and laminae (Table 1) were measured on longitudinal and tangential sections using Strommetric image analysis software (Wolniewicz, 2010). Skeletal features used in the present paper were traditionally employed in most studies of Actinostroma (e.g., Lecompte, 1951; Flügel, 1959; Kaźmierczak, 1971; Stock, 1984; Stearn, 1996; Salerno, 2008).

Many specimens from the Devonian of the Holy Cross Mountains show a close similarity to species erected by Lecompte (1951). Thus, the type specimens of these species (20 in total) were investigated by myself, and new skeletal measurements were made using Strommetric. Moreover, 46 specimens of the genera Actinostroma and Bifariostroma from the Devonian of the Holy Cross Mountains, which are part of the Kaźmierczak Collection (Kaźmierczak 1971), were also restudied.

\section{Systematic palaeontology}

The family Actinostromatidae is characterised by the presence of pillars (vertical elements, per- pendicular to the growth surface) and horizontal elements developed as a delicate network of colliculi (Stock, 2012), usually less prominent than pillars. The colliculi are formed by rods that join to form a network that is parallel to the growth surface (Stearn et al., 1999). This particular family comprises five genera, three of which recorded from the Devonian (Stock, 2012). Actinostroma is the most widespread genus of the family. It differs from Plectostroma Nestor, 1964 by having a horizontally aligned network of colliculi. The genus Bifariostroma, which comprises species previously assigned to Actinostroma, has pillars of two types: 1) long and thick (megapillars) and 2) short and thin, and horizontally aligned colliculi (Stock, 2012). The two other genera of the family (Bicolumnostratum Stock in Stock \& Burry-Stock, 1998 and Crumplestroma Khalfina, 1972) are of Silurian age.

To date, more than one hundred species of Actinostroma have been established, with at least 20 that were first described from the Givetian and/or Frasnian (Flügel, 1959). The diagnoses of species are based mostly on the internal structure of the skeleton and dimensions of the most prominent skeletal elements: 1) pillars and 2) laminae, which are composed of colliculi. Species diagnoses published by Kaźmierczak (1971) and Racki \& Sobstel (2004) are revised in the present work, following recent taxonomic concepts advocated after the pioneering monograph by Kaźmierczak came out (Stearn et al., 1999; Stock, 2012).

In order to ensure that measurement procedures are consistent, skeletal features of species established by Lecompte (1951) were measured directly from the holotypes. Some of them deviate from dimensions given by Lecompte (1951) and Flügel (1959) (Tables 1, 2). For all measurements median values are given.

Growth form terminology of stromatoporoids is based on Kershaw (1998). In some specimens, the external growth form could not be determined because of the orientation of a stromatoporoid in the sample. Broken stromatoporoids were classed as "tabular to low domical" and "low to high domical", because the exact V/B relationship (Kershaw, 1998) remained unknown. Oblique sections of a domical skeleton could be confused with a bulbous form, so these are also classed as "low to high domical". Exact basal lengths (B) and vertical heights (V) are indeterminable for most specimens, which explains why it is not possible to study the $\mathrm{V} / \mathrm{B}$ ratio in relation to basal diameter, and to illustrate variation in form between different ontogenetic stages amongst stromatoporoids. 
Table 2. Skeletal dimensions of species described in the present paper and of type specimens from the Lecompte Collection (Lecompte, 1951). Median values are supplied for all features. Abbreviations: no. - number of specimens; $x$ - arithmetic mean; $\sigma$ - standard deviation.

\begin{tabular}{|c|c|c|c|c|c|c|c|c|c|c|c|}
\hline & \multirow[b]{2}{*}{ no. } & \multicolumn{2}{|c|}{ Pillar width } & \multicolumn{2}{|c|}{$\begin{array}{l}\text { Thickness of } \\
\text { laminae }\end{array}$} & \multicolumn{2}{|c|}{ Pillar diameter } & \multicolumn{2}{|c|}{$\begin{array}{l}\text { Number of pil- } \\
\text { lars per } 2 \mathrm{~mm}\end{array}$} & \multicolumn{2}{|c|}{$\begin{array}{c}\text { Number of } \\
\text { laminae per } \\
2 \mathrm{~mm}\end{array}$} \\
\hline & & $x$ & $\sigma$ & $x$ & $\sigma$ & $x$ & $\sigma$ & $x$ & $\sigma$ & $x$ & $\sigma$ \\
\hline $\begin{array}{l}\text { Actinostroma cf. crassepil- } \\
\text { atum }\end{array}$ & 23 & 0.531 & 0.111 & 0.061 & 0.007 & 0.236 & 0.038 & 3.717 & 0.485 & 8.109 & 1.068 \\
\hline $\begin{array}{l}\text { Actinostroma crassepilatum } \\
\text { (holotype) }\end{array}$ & 1 & 0.567 & 0 & 0.063 & 0 & 0.241 & 0 & 3.000 & 0 & 6.000 & 0 \\
\hline $\begin{array}{l}\text { Actinostroma dehornae } \\
\text { (holotype) }\end{array}$ & 2 & 0.861 & 0.083 & 0.067 & 0.003 & 0.337 & 0 & 3.500 & 0.250 & 8.000 & 1.000 \\
\hline Actinostroma densatum & 17 & 0.644 & 0.251 & 0.065 & 0.007 & 0.261 & 0.054 & 3.970 & 0.542 & 7.721 & 1.003 \\
\hline $\begin{array}{l}\text { Actinostroma densatum } \\
\text { (type specimens) }\end{array}$ & 3 & 0.615 & 0.071 & 0.059 & 0.003 & 0.175 & 0.011 & 3.333 & 0.311 & 8.500 & 0.935 \\
\hline Actinostroma expansum & 16 & 0.657 & 0.477 & 0.062 & 0.006 & 0.226 & 0.048 & 3.594 & 0.649 & 7.969 & 0.996 \\
\hline $\begin{array}{l}\text { Actinostroma filitextum } \\
\text { (holotype) }\end{array}$ & 1 & 0.396 & 0 & 0.047 & 0 & 0.200 & 0 & 4.000 & 0 & 8.000 & 1.000 \\
\hline Actinostroma cf. geminatum & 5 & 0.465 & 0.074 & 0.063 & 0.005 & 0.189 & 0.014 & 3.09 & 0.199 & 8.440 & 1.661 \\
\hline $\begin{array}{l}\text { Actinostroma geminatum } \\
\text { (holotype) }\end{array}$ & 1 & 0.456 & 0 & 0.071 & 0 & 0.223 & 0 & 4.000 & 0 & 8.000 & 1.000 \\
\hline Actinostroma papillosum & 11 & 0.508 & 0.051 & 0.067 & 0.007 & 0.196 & 0.058 & 3.545 & 0.486 & 8.386 & 1.013 \\
\hline $\begin{array}{l}\text { Actinostroma sertiforme } \\
\text { (holotype) }\end{array}$ & 1 & 0.444 & 0 & 0.071 & 0 & 0.174 & 0 & 4.000 & 0 & 7.500 & 0 \\
\hline Actinostroma stellulatum & 13 & 0.463 & 0.118 & 0.063 & 0.007 & 0.176 & 0.02 & 3.788 & 0.579 & 9.269 & 1.054 \\
\hline Actinostroma verrucosum & 2 & 0.485 & 0.011 & 0.082 & 0.002 & 0.168 & 0.013 & 4.125 & 0.125 & 7.500 & 0 \\
\hline Bifariostroma bifarium & 3 & 0.472 & 0.171 & 0.056 & 0.004 & 0.295 & 0 & 3.333 & 0.471 & 8.750 & 1.274 \\
\hline Bifariostroma sp. & 2 & 0.717 & 0.166 & 0.070 & 0.001 & 0.283 & 0 & 3.500 & 0 & 8.000 & 1.000 \\
\hline
\end{tabular}

Specimens studied are housed at the Institute of Geology, Adam Mickiewicz University, Poznań, Poland (institutional abbreviation: UAM).

Order Actinostromatida Bogoyavlenskaya, 1969

Family Actinostromatidae Nicholson, $1886 \mathrm{~b}$

Genus Actinostroma Nicholson, 1886b

Actinostroma cf. A. crassepilatum Lecompte, 1951

Figure 4A-C

1971 Actinostroma crassepilatum Lecompte; Kaźmierczak, p. 137, pl. 40, fig. 3; pl. 41, fig. 6 (part). 2004 Actinostroma cf. A. crassepilatum Lecompte;

Racki \& Sobstel, p. 86, figs. 3-4.

Material. Twenty-three specimens from the Lower Sitkówka Beds (UAM-OLO 10, UAM-OLO 20, UAM-OLO 21, UAM-SOG 1, UAM-SOG 14), Upper Sitkówka Beds (UAM-STO 17, UAM-ZEL 8, UAM-ZEL 11, UAM-ZEL 12), Detrital Beds (UAMGRA 4, UAM-GRA 11, UAM-GRA 13, UAM-GRA 20, UAM-GRA 23, UAM-GRA 109, UAM-GRA 111, UAM-GRA 112, UAM-GRA 116, UAM-GRA 117, UAM-KOD 1, UAM-KOD 2, UAM-KOD 4) and Wietrznia Beds (UAM-WIE 3). Two specimens in the Kaźmierczak Collection (1971): Z. Pal. St.I/250,
St.I/440, sampled from the Upper Sitkówka Beds and/or Kadzielnia Limestone Member.

Description. Skeleton tabular or domical with enveloping laminae. In most specimens prominent growth inhibition surfaces and/or latilaminae present. Low mamelons (up to $2 \mathrm{~mm}$ high) in some specimens. Astrorhizae absent. Laminae 0.05-0.085 mm thick, spaced 6-10 in $2 \mathrm{~mm}$, single layer, planar or slightly undulating, with poorly visible colliculi, locally interrupted by pores. Dissepiments rare. Pillars significantly thicker than laminae $(0.17-0.29$ $\mathrm{mm}$ thick), intersecting up to 15 interlaminar spaces, $0.34-0.87 \mathrm{~mm}$ long, straight, with lighter central zones in places, locally intersected by laminae, straight or curved, irregularly spaced, 3-5 in $2 \mathrm{~mm}$.

Remarks. Actinostroma cf. A. crassepilatum differs from $A$. expansum in having planar, continuous laminae and from $A$. densatum in having continuous laminae with poorly visible colliculi in longitudinal thin sections. It differs from other species studied here in having pillars that are significantly thicker than laminae.

Specimens of Actinostroma from the Holy Cross Mountains, which show pillars that are significantly thicker than laminae, were assigned to $A$. 


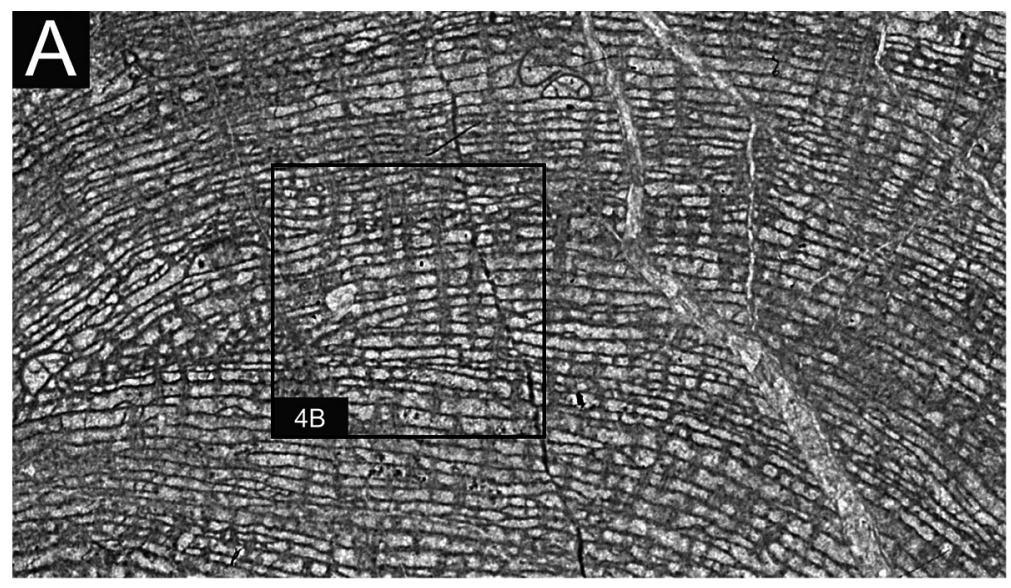

Fig. 4. Actinostroma cf. A. crassepilatum Lecompte 1951. Scale bars equal 1 mm; A - longitudinal thin section of specimen UAMOLO 20 (width of image: $17 \mathrm{~mm}$ ); B - close-up of the same section; $\mathbf{C}$ - tangential thin section of specimen UAM-KOD 2.
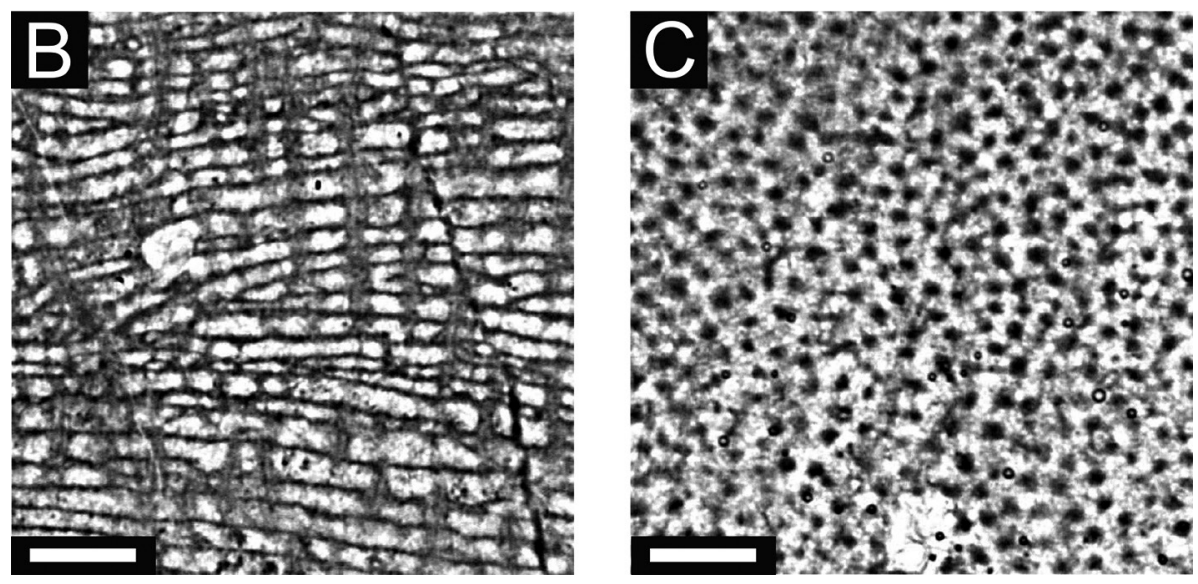

crassepilatum Lecompte, 1951 and A. cf. A. crassepilatum (compare Kaźmierczak, 1971; Racki \& Sobstel, 2004). Skeletal features of specimens studied are similar to those of the holotype of A. crassepilatum. However, the laminae are more planar, mamelons are small and rare, astrorhizae are absent, and skeletal elements are more densely packed.

Actinostroma densatum Lecompte, 1951

Figure 5A-E

1951 Actinostroma densatum Lecompte, p. 94, pl. 3,

figs. 7-8.

1956 Actinostroma densatum Lecompte; Flügel, p.

140, pl. 1, fig. 3.

1971 Actinostroma compactum Ripper; Kaźmierczak, p. 131, pl. 37, fig. 1.

1971 Actinostroma crassepilatum Lecompte;

Kaźmierczak, p. 137, pl. 40, fig. 3; pl. 41, fig. 6

(part).

1971 Actinostroma expansum (Hall and Whitfield);

Kaźmierczak, p. 136, pl. 40, fig. 2; pl. 41, fig. 5

(part).

1971 Actinostroma stellulatum Nicholson;

Kaźmierczak, p. 133, pl. 37, fig. 3 (part).
1981 Actinostroma densatum Lecompte; Zukalová, p. 677.

For a complete synonymy list, reference is made to Krebedünkel (1995, p. 40).

Material. Seventeen specimens from the Stringocephalus Beds (UAM-DZI 1, UAM-DZI 4, UAMDZI 15), the Lower Sitkówka Beds (UAM-LGA 14, UAM-LGA 25, UAM-OLO 5, UAM-OLO 8, UAMOLO 13, UAM-OLO 14, UAM-OLO 15, UAM-SOG 9), Upper Sitkówka Beds (UAM-LGA 22, UAMLGA 23) and Detrital Beds (UAM-GRA 21, UAMGRA 105, UAM-GRA 120, UAM-GRA 121). Nine specimens in the Kaźmierczak Collection (1971): Z. Pal. St.I/264, St.I/268, St.I/271, St.I/275, St.I/282, St.I/296, St.I/356, St.I/417, St.I/465, most of them recovered from the Stringocephalus Beds and Upper Sitkówka Beds.

Description. Skeleton domical, latilaminate in some specimens. Mamelons rare, low (up to $2 \mathrm{~mm}$ high). Astrorhizae present, poorly developed. Laminae 0.055-0.085 mm thick, single layer, planar, broken into line of colliculi, closely spaced (6-10 in $2 \mathrm{~mm}$ ). Colliculi well defined in tangential sections, forming a network in laminae. Dissepiments common in places. Pillars significantly thicker than 

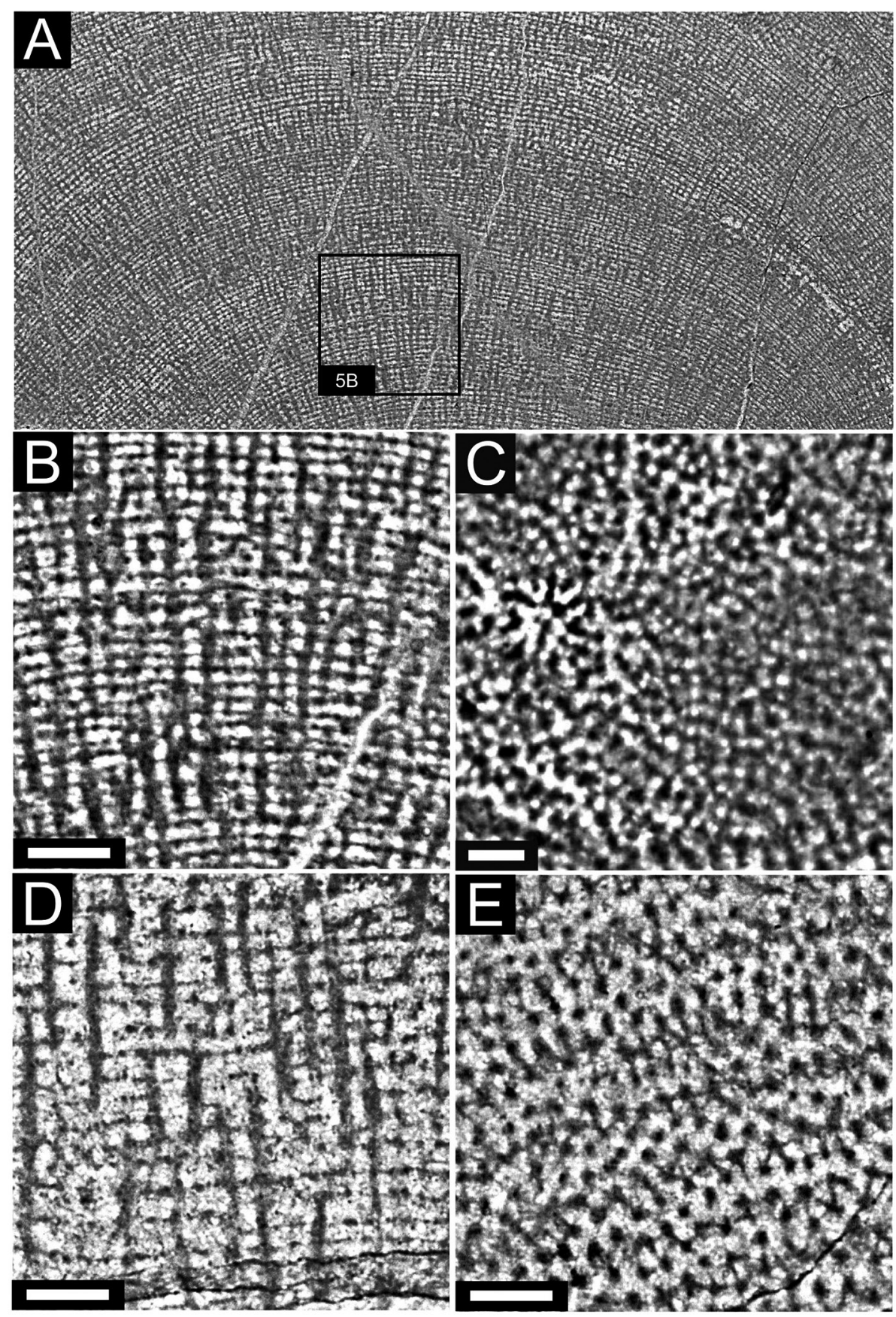

Fig. 5. Actinostroma densatum Lecompte, 1951. Scale bars equal $1 \mathrm{~mm}$ : A - longitudinal thin section of specimen UAM-LGA 22 (width of image: $33 \mathrm{~mm}$ ); B - close-up of the same section; C - tangential thin section of the same specimen (note presence of small astrorhiza on lefthand side in photograph); D - longitudinal section of specimen UAM-GRA 105, showing laminae reduced to widely spaced colliculi and thick pillars; E - tangential thin section of the same specimen.

laminae (0.16-0.33 mm thick), intersecting up to 20 interlaminar spaces, $0.40-1.54 \mathrm{~mm}$ long, straight, irregularly spaced, locally spaced up to 5 pillars in 2 $\mathrm{mm}$; in other places pillars spaced 3 in $2 \mathrm{~mm}$.

Remarks. Actinostroma densatum differs from $A$. expansum in having straight, thick pillars, while $A$. cf. A. crassepilatum shows poorly defined laminae in longitudinal thin sections. Actinostroma densatum differs from other species studied here in having long pillars that are significantly thicker than laminae.
The holotype of $A$. densatum shows laminae that are more densely packed than the ones in specimens from Poland (Table 2). Pillars are thicker in material from the Holy Cross Mountains than in the type specimen. Other features of specimens from Poland are similar to those of the holotype of A. densatum.

Specimen UAM-GRA 105 (Fig. 5D-E) and four specimens from the Kaźmierczak Collection (St.I/275, St.I/296, St.I/356, St.I/465) reveal laminae that are reduced to loosely spaced colliculi and thick $(>0.11 \mathrm{~mm}$ ) pillars, thus resembling the type specimen of Actinostroma tabulatum var. crassum Le- 
compte, 1951. Nevertheless, they are here included in A. densatum, because other specimens of A. densatum also show reduced laminae in places.

Actinostroma expansum (Hall and Whitfield, 1873) Figure 6A-E

1873 Stromatopora expansa Hall and Whitfield, p. 226, pl. 9, fig. 1.

1971 Actinostroma papillosum (Bargatzky); Kaźmierczak, p. 134, pl. 38, fig. 1; pl. 40, fig. 1 (part).
1971 Actinostroma expansum (Hall and Whitfield); Kaźmierczak, p. 136, pl. 40, fig. 2; pl. 41, fig. 5 (part).

1971 Actinostroma crassepilatum Lecompte; Kaźmierczak, p. 137, pl. 40, fig. 3; pl. 41, fig. 6 (part).

For a complete synonymy list, reference is made to Stock (1984, p. 774), Krebedünkel (1995, p. 43) and Stearn (1996, p. 200).

Material. Sixteen specimens from the Stringocephalus Beds (UAM-DZI 7, UAM-DZI 23), the Lower

Fig. 6. Actinostroma expansum (Hall and Whitfield, 1873). Scale bars equal 1 $\mathrm{mm}$; A - longitudinal thin section of specimen UAM-OLO 12 (width of image: $19 \mathrm{~mm}$ ); B - longitudinal thin section of specimen UAMKDZ 4; C - tangential thin section of the same specimen; D - closeup of longitudinal thin section of specimen UAM-OLO 12, showing straight pillars and densely spaced laminae with well-preserved colliculi; E - tangential thin section of specimen UAM-OLO 19; note the presence of small astrorhiza on right-hand side in photograph.

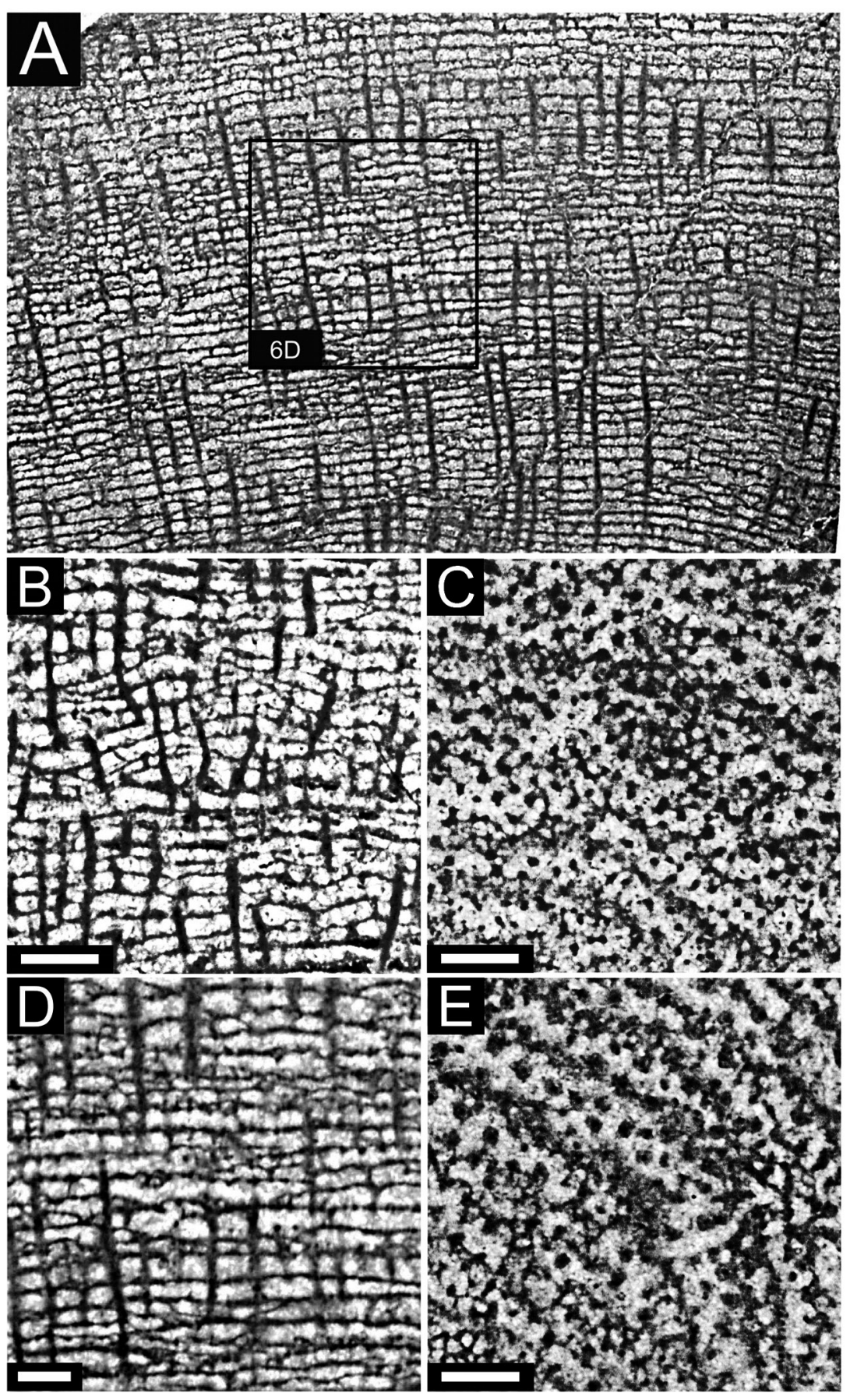


Sitkówka Beds (UAM-DEB 7, UAM-DEB 10, UAMDEB 30, UAM-OLO 1, UAM-OLO 9, UAM-OLO 12, UAM-OLO 16, UAM-OLO 19, UAM-OLO 22, UAM-STO 73, UAM-STO 74) and the Kadzielnia Member (UAM-KDZ 4, UAM-LGA 20, UAM-LGA 26). 13 specimens in the Kaźmierczak Collection (1971): Z. Pal. St.I/245, St.I/260, St.I/261, St.I/262, St.I/263, St.I/265, St.I/270, St.I/276, St.I/357, St.I/441, St.I/443, St.I/444, St.I/468, most of them collected from the Stringocephalus Beds and Upper Sitkówka Beds.

Description. Skeleton tabular to low domical; some skeletons conspicuously latilaminate; latilaminae about 4-10 mm thick. Mamelons rare. Poorly developed astrorhizae in some specimens. Laminae thin $(0.05-0.07 \mathrm{~mm})$, single layer, planar or sinuous, breaking into line of colliculi, spaced 6-11 in $2 \mathrm{~mm}$. Colliculi well defined in tangential sections, forming a delicate network in laminae. Dissepiments common in places, locally substituting for laminae. Pillars thicker than laminae (0.15-0.32 mm), long (0.36-2.41 mm), intersecting up to 25 interlaminar spaces, irregularly spaced (2-5 in $2 \mathrm{~mm}$ ), expanded at laminae in some specimens, straight or curved.

Remarks. Actinostroma expansum differs from $A$. densatum in having thinner and commonly curved pillars, and from A. cf. A. crassepilatum in having laminae broken into the line of colliculi. Other species studied show pillars that are not significantly thicker than laminae.

Six skeletons from the Lower Sitkówka Beds at Ołowianka (Fig. 6D-E) and five specimens from the Kaźmierczak Collection (St.I/261, St.I/270, St.I/357, St.I/443, St.I/468) show straight pillars and densely spaced laminae (8-10 in $2 \mathrm{~mm}$ ) with well-preserved colliculi in longitudinal sections. Similar specimens from the Frasnian of the Boulonnais (northwest France) were described by Mistiaen (1988, fig. 5.1) as Actinostroma cf. A. filitextum Lecompte, 1951. However, it is not clear if specimens from the Holy Cross Mountains that have densely spaced laminae represent a separate species or a continuum of variation within the same taxon. Thus, they are here included in A. expansum. Measurements of Polish material fall within the range of variation of the type specimens of A. expansum (Stock, 1984).

Actinostroma cf. A. geminatum Lecompte, 1951 Figure 7A-E

1971 Actinostroma aff. geminatum Lecompte;

Kaźmierczak, p. 132, pl. 37, fig. 2.

Material. Five specimens from the Upper Sitkówka Beds (UAM-LGA 4, UAM-LGA 6, UAM-LGA 11, UAM-LGA 12, UAM-LGA 52). Two speci- mens in the Kaźmierczak Collection (1971): Z. Pal. St.I/383, St.I/410, from the Lower Sitkówka Beds.

Description. Skeleton tabular or low domical. Mamelons rare, low (up to $2 \mathrm{~mm}$ in height), with poorly developed astrorhizae visible solely in tangential sections. Laminae continuous, planar, rarely wrinkled, 0.05-0.075 mm thick, densely and unevenly spaced (7-11 in $2 \mathrm{~mm})$, commonly in pairs. Latilaminae present in few specimens. Colliculi well preserved in tangential sections. Dissepiments rare. Most pillars short (0.35-0.55 $\mathrm{mm}$ in length), intersecting one interlaminar space, straight or oblique, often dichotomously branched in their upper parts, spaced 4 in $2 \mathrm{~mm}$, slightly thicker than laminae (0.15-0.20 mm). Long pillars present in places, intersecting up to eight interlaminar spaces, straight or curved, irregularly spaced within skeleton.

Remarks. Actinostroma cf. A. geminatum differs from $A$. cf. A. crassepilatum, A. densatum and $A$. expansum in having pillars that are of comparable thickness to laminae. Actinostroma papillosum has numerous long, straight pillars, while A. stellulatum differs from $A$. cf. A. geminatum in having thinner laminae.

The holotype of A. geminatum shows more prominent astrorhizae that are visible in longitudinal thin sections. Laminae are slightly thicker in the holotype (median value $0.071 \mathrm{~mm}$ ). The species was first described from the Eifelian at Couvin in southern Belgium.

Two specimens (UAM-LGA 11, UAM-LGA 12; see Fig. 7D-E) reveal laminae that are broadened by complexly arranged colliculi, forming a delicate network in tangential sections, resembling Actinostroma verrucosum (Goldfuss, 1826) from the Middle Devonian. However, the internal structure of the laminae is less complex in specimens studied than in typical representatives of A. verrucosum (see e.g., Mistiaen, 1980); in addition, the Polish material is of early Frasnian age.

\section{Actinostroma papillosum (Bargatzky, 1881)}

Figure 8A-C

1881 Stromatopora papillosa Bargatzky, p. 54. 1971 Actinostroma stellulatum Nicholson;

Kaźmierczak, p. 133, pl. 37, fig. 3 (part).

For a complete synonymy list, reference is made to Cockbain (1984, p. 15) and Krebedünkel (1995, p. 27).

Material. Eleven specimens from the Stringocephalus Beds (UAM-OLOSTR 2, UAM-OLOSTR 3, UAM-OLOSTR 5, UAM-OLOSTR 9), the Lower Sitkówka Beds (UAM-OLO 17, UAM-SOG 15, UAM-SOG 17, UAM-SOG 19, UAM-STO 3), Upper Sitkówka Beds (UAM-ZEL 3) and Wietrznia 


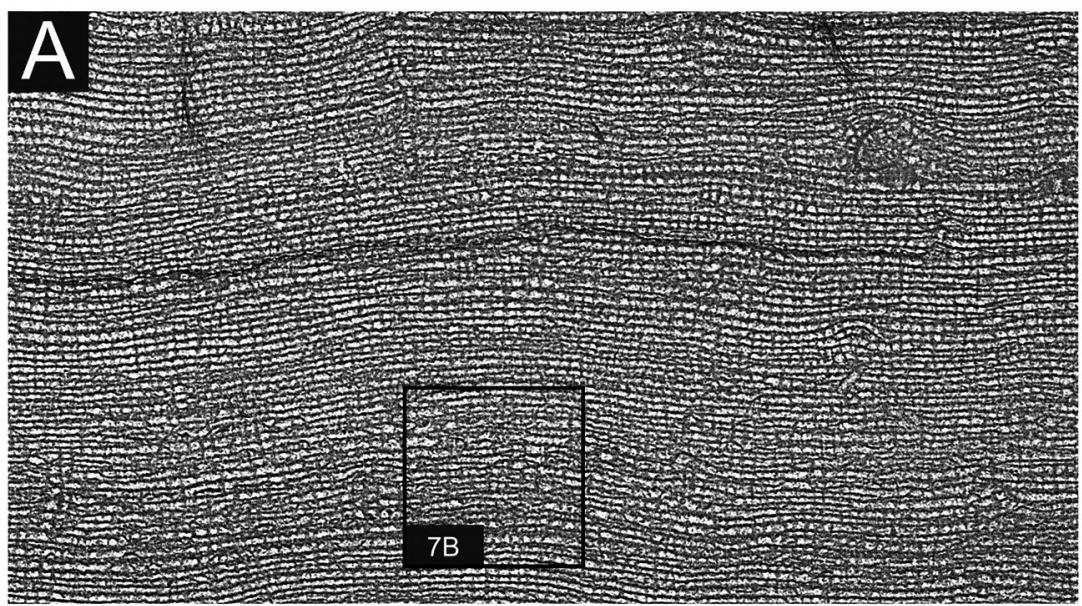

Fig. 7. Actinostroma cf. A. geminatum Lecompte, 1951. Scale bars equal 1 mm; A - longitudinal thin section of specimen UAM-LGA 4 (width of image: $23 \mathrm{~mm}$ ); B - close-up of the same section; C - tangential thin section of the same specimen; D - longitudinal thin section of specimen UAM-LGA 12, showing laminae broadened by complexly arranged colliculi; E - tangential thin section of the same specimen.

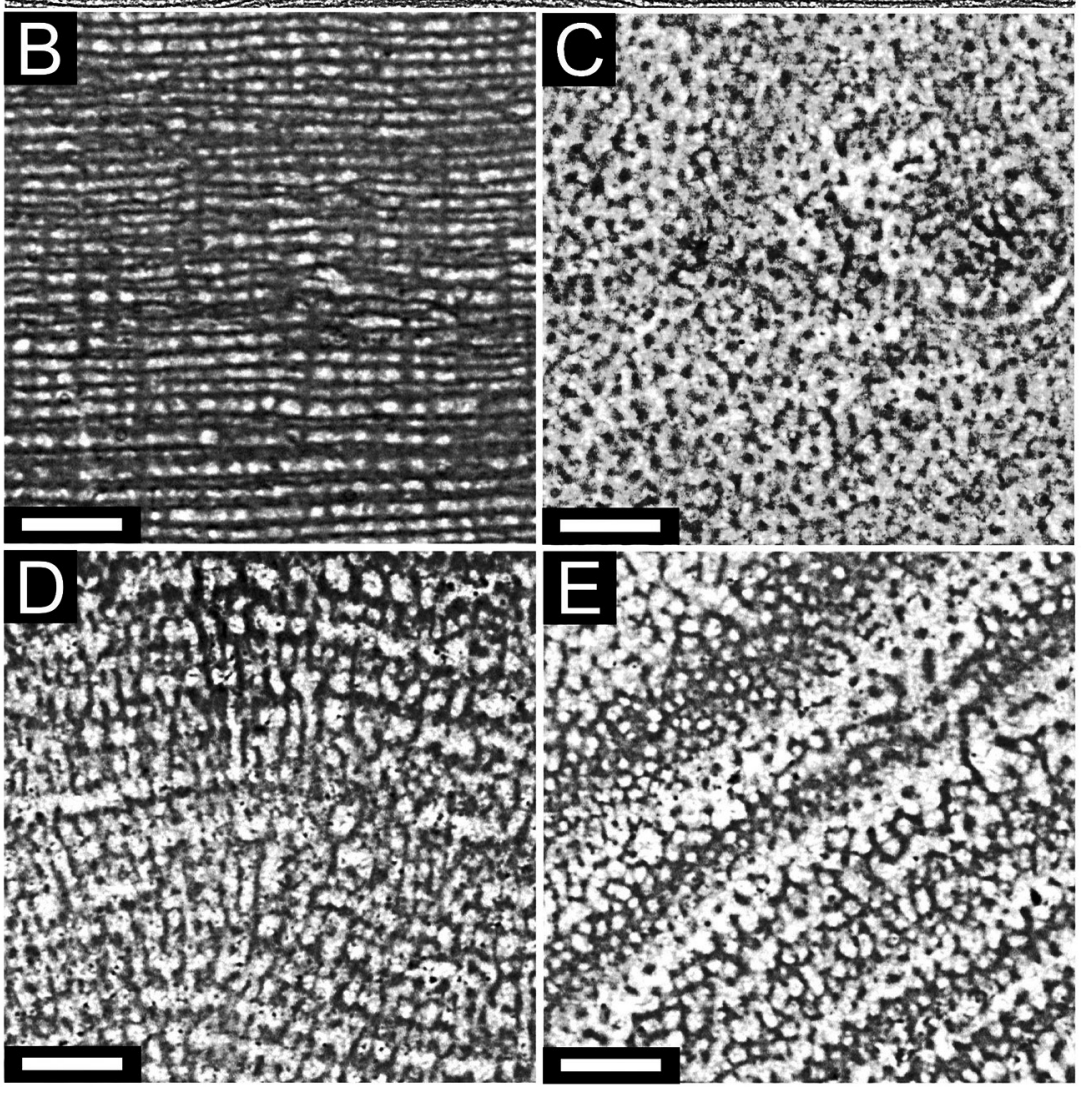

Beds (UAM-WIE 4). A single specimen in the Kaźmierczak Collection (1971): Z. Pal. St.I/269, from the Upper Sitkówka Beds.

Description. Skeleton tabular to low domical. Mamelons small, up to $3 \mathrm{~mm}$ high, rounded. No obvious astrorhizae. Laminae continuous, planar or undulating, broken into line of colliculi in places, of variable thickness (0.06-0.08 mm thick), spaced 7-10 in $2 \mathrm{~mm}$. Latilaminae present in most specimens, 3-6 mm thick. Colliculi well preserved in tangential sections, forming a network even between laminae. Dissepiments rare. Pillars long (0.41-0.58 $\mathrm{mm})$, intersecting up to 25 interlaminar spaces, spaced $3-5$ in $2 \mathrm{~mm}$, slightly thicker than laminae
(0.15-0.25 mm), in some specimens expanded at laminae.

Remarks. A. papillosum differs from all species studied in having long pillars and in possessing laminae that are slightly thicker than pillars or comparable in thickness to them. In parts of the skeleton where laminae are thicker and densely spaced $A$. papillosum is comparable to $A$. cf. A. geminatum, but long pillars visible in other places allow differentiation of these two taxa.

Differentiation between $A$. papillosum and $A$. clathratum Nicholson, 1886a poses significant problems (Cockbain, 1984; Stearn, 1996). Intraskeletal variation in specimens from the Holy Cross Moun- 
tains significantly exceeds that described by Flügel (1959). The pillars, measured in tangential sections, are slightly thicker than laminae. However, in longitudinal thin sections the thickness of laminae and pillars is similar, which is diagnostic for A. papillosum.
Actinostroma stellulatum Nicholson, 1886a

Figures 8D, 9A-F

1886a Actinostroma stellulatum Nicholson, p. 231, pl. 6, figs. 8-9.

1971 Actinostroma stellulatum Nicholson;

Kaźmierczak, p. 133, pl. 37, fig. 3 (part).

For a complete synonymy list, reference is made to Salerno (2008, p. 60).
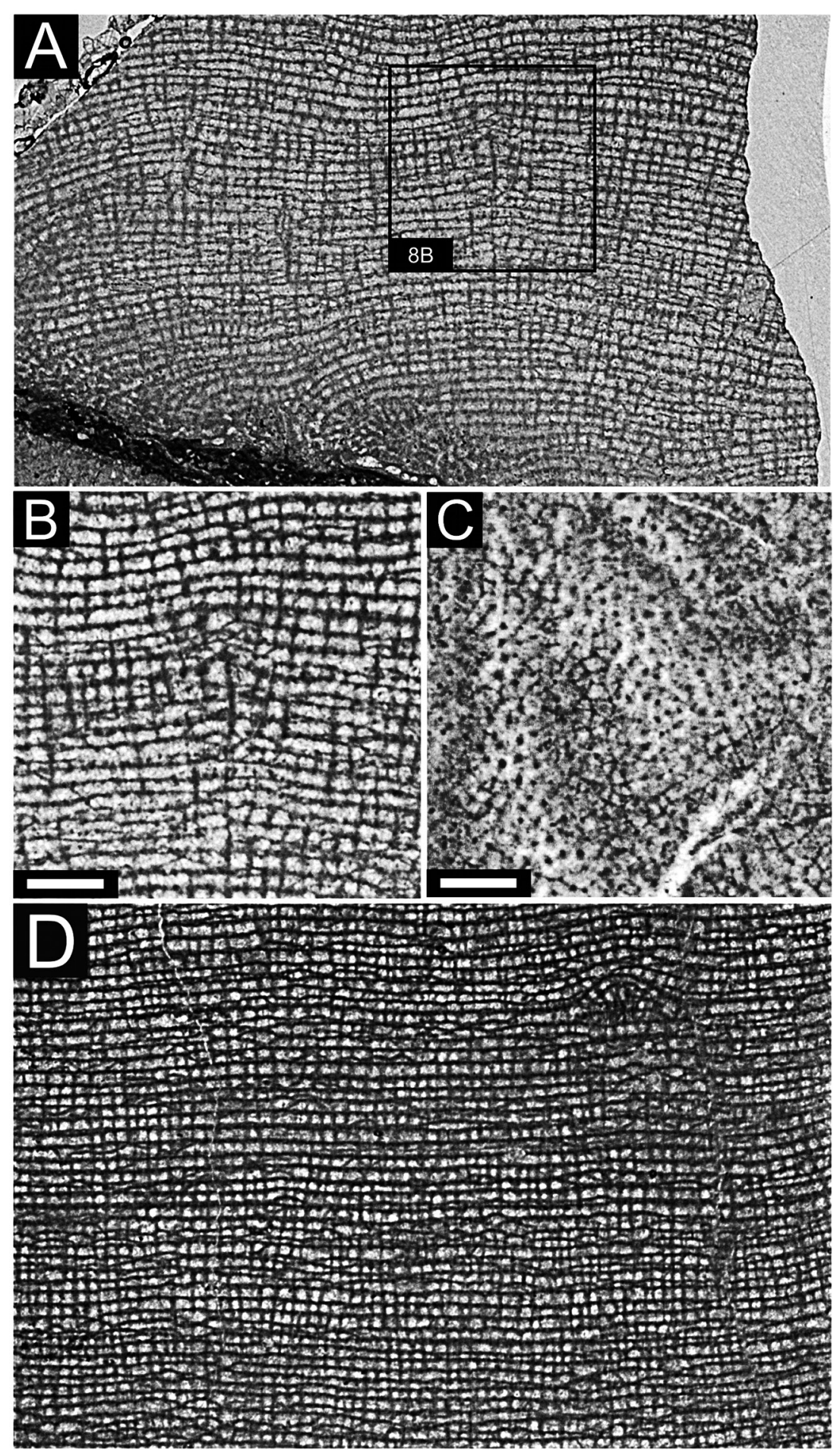

Fig. 8. A-C - Actinostroma papillosum (Bargatzky, 1881); D - Actinostroma stellulatum Nicholson, 1886a. Scale bars equal $1 \mathrm{~mm}$; A - longitudinal thin section of specimen UAM-SOG 17 (width of image: $16 \mathrm{~mm}$ ); B - close-up of the same section; C - tangential thin section of specimen UAM-OLOSTR 5; D - longitudinal thin section of specimen UAM-SOG 16 (width of image: $15 \mathrm{~mm}$ ). 

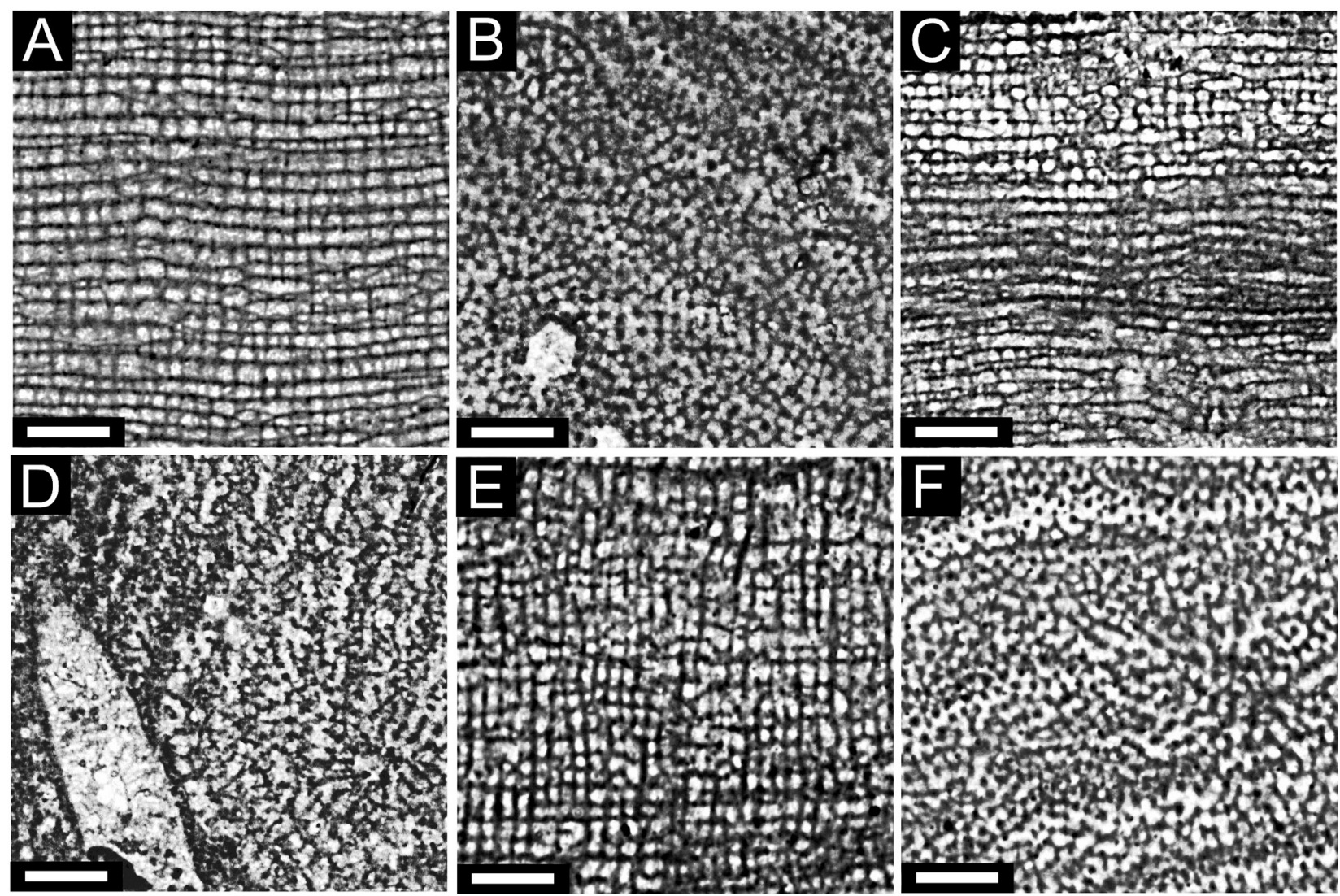

Fig. 9. Actinostroma stellulatum Nicholson, 1886a. Scale bars equal $1 \mathrm{~mm}$; A - longitudinal thin section of specimen UAM-SOG 16; B - tangential thin section of the same specimen; C - longitudinal thin section of specimen UAMZEL 9, showing undulating laminae in the upper part of the photograph; D - tangential thin section of the same specimen; E - longitudinal thin section of specimen UAM-DZI 6, showing poorly aligned colliculi; F - tangential thin section of the same specimen.

Material. Fifteen specimens from the Stringocephalus Beds (UAM-DZI 6, UAM-DZI 16, UAMDZI 22), the Lower Sitkówka Beds (UAM-DEB 19, UAM-OLO 2, UAM-OLO 11, UAM-SOG 4, UAM-SOG 16, UAM-STO 2, UAM-STO 71) and Upper Sitkówka Beds (UAM-STO 56, UAM-ZEL 1, UAM-ZEL 5, UAM-ZEL 7, UAM-ZEL 9). Four specimens in the Kaźmierczak Collection (1971): Z. Pal. St.I/274, St.I/277, St.I/323, St.I/388, from the Lower Sitkówka Beds.

Description. Skeleton tabular to low domical. Mamelons small, up to $2 \mathrm{~mm}$ in height, some with poorly developed astrorhizal canals. Laminae thin (0.05-0.08 $\mathrm{mm}$ thick), continuous, planar, spaced 7-10 in $2 \mathrm{~mm}$. Colliculi well developed. Dissepiments common in places, locally substituting for laminae. Pillars of variable length $(0.37-0.79 \mathrm{~mm})$, many short, confined to an interlaminar space, other long, intersecting up to five interlaminar spaces. Pillars thin (0.06-0.085 mm thick), slightly thicker than laminae, straight, round in tangential sections, spaced $3-5$ in $2 \mathrm{~mm}$.
Remarks. Actinostroma stellulatum differs from $A$. cf. A. crassepilatum, A. densatum and A. expansum in having laminae and pillars that are of comparable thickness. Actinostroma cf. A. geminatum has thicker and more complex laminae, while $A$. papillosum has long pillars, intersecting more than 10 interlaminar spaces.

Some specimens (e.g., UAM-ZEL 9; see Fig. 9C-D) show undulating laminae in parts of the skeleton, resembling the skeletal structure of $A c-$ tinostroma sertiforme Lecompte, 1951. However, in tangential thin sections a delicate network formed by colliculi is visible, contrary to the situation in $A$. sertiforme, which shows poorly developed colliculi.

Specimens from the middle Givetian Stringocephalus Beds (Fig. 9E-F) show poorly aligned colliculi in parts of the skeleton, which is a diagnostic feature of the genus Plectostroma. However, in the entire skeleton horizontally aligned colliculi predominate, and thus the specimens studied need to be assigned to Actinostroma. 
Actinostroma verrucosum (Goldfuss, 1826)

Figure 10A-C

For a complete synonymy list, reference is made to Salerno (2008, p. 63).

Material. Two specimens from the Stringocephalus Beds (UAM-DZI 9, UAM-DZI 25).

Description. Skeleton low domical, latilaminate. Mamelons indistinct, low, up to $4 \mathrm{~mm}$ hin height. Astrorhizal canals present, short (up to $3 \mathrm{~mm}$ long), up to $0.2 \mathrm{~mm}$ across. Laminae thick $(>0.07 \mathrm{~mm})$, with complex internal structure formed by complexly arranged colliculi, planar or undulating, regularly spaced (7-8 in $2 \mathrm{~mm})$. Pillars short (0.45-0.5 $\mathrm{mm})$, straight, V-shaped; most confined to an inter- laminar space, others intersecting up to 7 interlaminar spaces, thin $(0.15-0.20 \mathrm{~mm})$, regularly spaced (4 in $2 \mathrm{~mm}$ ), rounded or star like, joined by colliculi in a delicate network even between laminae.

Remarks. Actinostroma verrucosum differs from all other species studied here, with the exception of $A$. cf. A. geminatum, in having laminae broadened by complexly arranged colliculi. It differs from $A$. cf. A. geminatum in possessing well-defined colliculi that form a delicate network in tangential sections.

\section{Genus Bifariostroma Khalfina, 1968}

Bifariostroma bifarium (Nicholson, 1886a)

Figures 10D, 11A-B
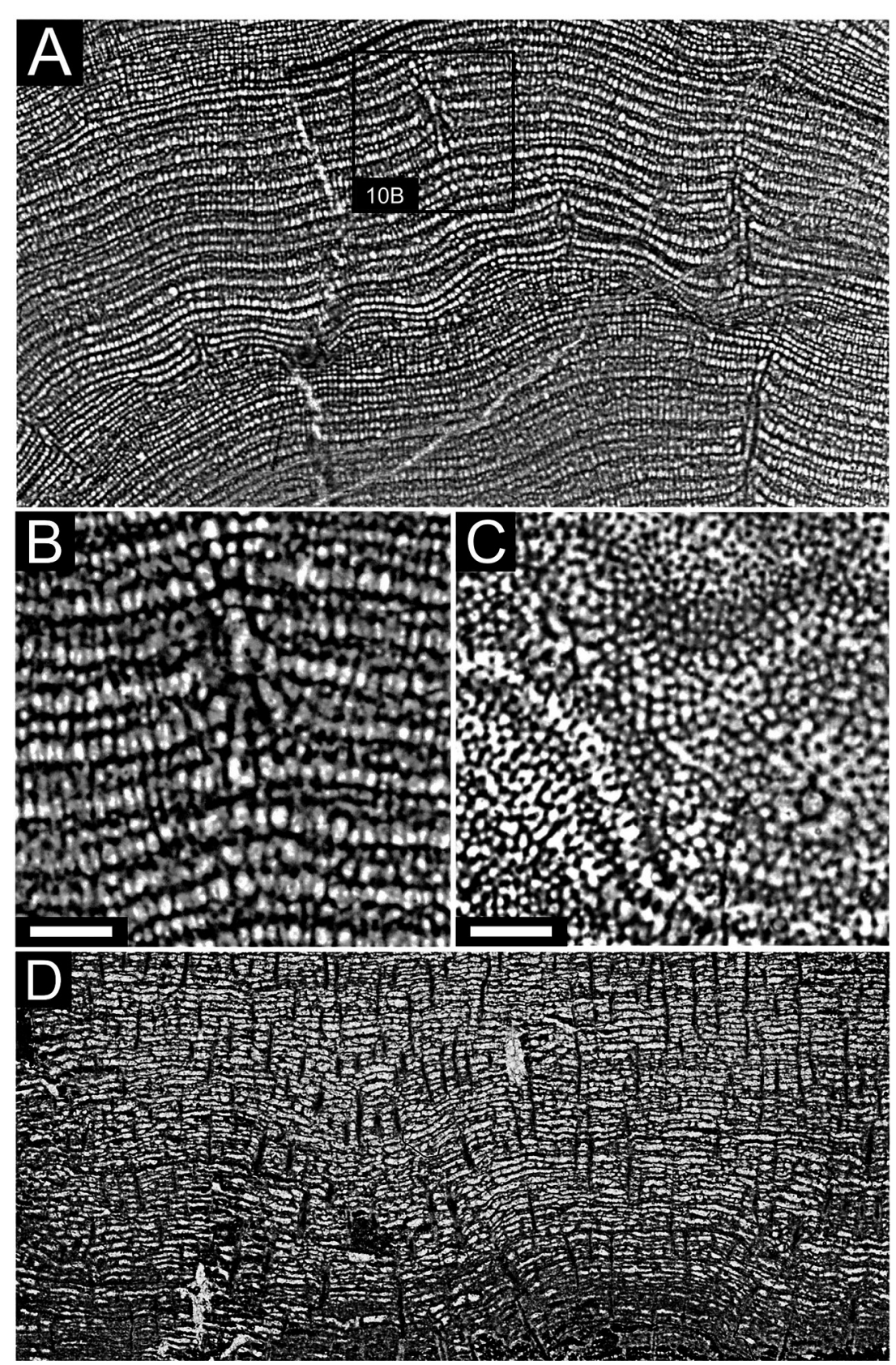

Fig. 10. A-C - Actinostroma verrucosum (Goldfuss, 1826); D - Bifariostroma bifarium (Nicholson, 1886a). Scale bars equal $1 \mathrm{~mm}$; A - longitudinal thin section of specimen UAMDZI 25 (width of image: $30 \mathrm{~mm}$ ); B - close-up of the same section; C - tangential thin section of the same specimen; D - longitudinal thin section of specimen UAMKOW 24 (width of image: $25 \mathrm{~mm}$ ). 
1886a Actinostroma bifarium Nicholson, p. 231, pl. 6, figs. 4-5.

1971 Actinostroma stellulatum Nicholson; Kaźmierczak, p. 133, pl. 37, fig. 3 (part).

1971 Actinostroma bifarium Nicholson; Kaźmierczak, p. 135, pl. 38, figs. 2-3; pl. 39, figs. 1-2 (part). 1971 Actinostroma crassepilatum Lecompte; Kaźmierczak, p. 137, pl. 40, fig. 3; pl. 41, fig. 6 (part).

For a complete synonymy list, reference is made to Mistiaen (1980, p. 184) and Krebedünkel (1995, p. 32).

Material. Three specimens from the Kadzielnia Member (UAM-KOW 24, UAM-KOW 41, UAMLGA 1), plus 10 specimens from the Kaźmierczak Collection (1971): Z. Pal. St.I/246, St.I/248, St.I/253, St.I/254, St.I/255, St.I/256, St.I/257, St.I/258, St.I/259, St.I/266, most of them recovered from the Upper Sitkówka Beds and the Kadzielnia Limestone Member.

Description. Skeleton tabular or low domical. Mamelons rare, astrorhizae absent. Laminae thin (0.05-0.06 mm), locally reduced, densely spaced (7-10 in $2 \mathrm{~mm})$, sinuous, locally invaginating into pillars. Dissepiments rare, locally substituting for laminae or joining neighbouring laminae. Pillars of two types: 1) long, intersecting up to 35 interlaminar spaces, thick $(0.29 \mathrm{~mm})$, straight or curved, with darker central parts; 2) short, intersecting up to three interlaminar spaces, thin $(0.06 \mathrm{~mm})$, oblique.

Remarks. Bifariostroma bifarium differs from Bifariostroma sp. in having sinuous laminae that invaginate into pillars.

\section{Bifariostroma sp.}

Figure 11C-E

1971 Actinostroma bifarium Nicholson;

Kaźmierczak, p. 135, pl. 38, figs. 2-3; pl. 39, figs.

1-2 (part).

1971 Actinostroma crassepilatum Lecompte;

Kaźmierczak, p. 137, pl. 40, fig. 3; pl. 41, fig. 6 (part).

Material. Two specimens from the Upper Sitkówka Beds (UAM-LGA 10, UAM-LGA 18). Five specimens in the Kaźmierczak Collection (1971): Z. Pal. St.I/244, St.I/251, St.I/252, St.I/273, St.I/466, most of them collected from the Upper Sitkówka Beds and the Kadzielnia Limestone Member.

Description. Skeleton tabular. Mamelons rare, high (up to $8 \mathrm{~mm}$ in height), with poorly developed astrorhizae. Laminae continuous, planar, broken into line of colliculi where best preserved, 0.06-0.07 $\mathrm{mm}$ thick, spaced 7-9 in $2 \mathrm{~mm}$. Latilaminae present, about 4-7 mm thick. Colliculi well defined in tangential thin sections, forming networks in laminae and between megapillars. Pillars of two types: 1) long megapillars, intersecting up to 15 interlaminar spaces, thick (0.42 mm), straight, expanded slightly at laminae; 2$)$ short, thin $(0.12 \mathrm{~mm})$, intersecting up to two interlaminar spaces, straight, dichotomously branching at tops.

Remarks. Bifariostroma sp. differs from B. bifarium in having planar laminae. Colliculi are well defined in the present form, while latilaminae are less conspicuous in B. bifarium.

\section{Discussion}

Genera of the family Actinostromatidae occur at most localities and in most stratigraphical units of the Kowala Formation. They are abundant within the stromatoporoid assemblages of the Upper Sitkówka Beds and Detrital Beds (Table 3). Actinostromatids are the main components of stromatoporoid faunas in four intensively sampled sections: Ołowianka and Sowie Górki (Stringocephalus Beds and Lower Sitkówka Beds), Góra Łgawa and Zelejowa Góra (Upper Sitkówka Beds). These sites, situated in the Southern Kielce subregion, belonged during the late Givetian-early Frasnian to the Miedzianka elevation, where non-rigid stromatoporoid buildups and biostromes gave rise to the early Frasnian symmetrical organic buildup. In contrast, actinostromatids were less common or absent in the surrounding deeper depositional basins, forming a stagnant Sitkówka depression at the GivetianFrasnian boundary (Sitkówka-Kostrzewa, Sołtysia Góra, Stokówka). Redeposited and abraded skeletons of Actinostroma are also abundant within the Detrital Beds, which flanked the organic buildup that emerged in the Kielce area during the early Frasnian. Representatives of Actinostroma expansum, common in the Lower Sitkówka Beds and within the Kadzielnia Member, that are commonly encrusted by other stromatoporoids (Fig. 3F), acted as stabilisers on a muddy sea floor. The wave-resistant organic buildup of the Kielce area was dominated by Actinostroma cf. A. crassepilatum.

The most diversified actinostromatid faunas were found within the middle Givetian Stringocephalus Beds (five species), in the upper Givetianlower Frasnian biostromal complex of the Lower Sitkówka Beds (five species) and in early Frasnian organic buildups (Upper Sitkówka Beds; six species). In spite of a similar sampling effort only two species were encountered in the stromatoporoid detrital facies which surrounded the Frasnian carbonate buildup. However, it must be noted that the Frasnian carbonate shelf became more differentiat- 

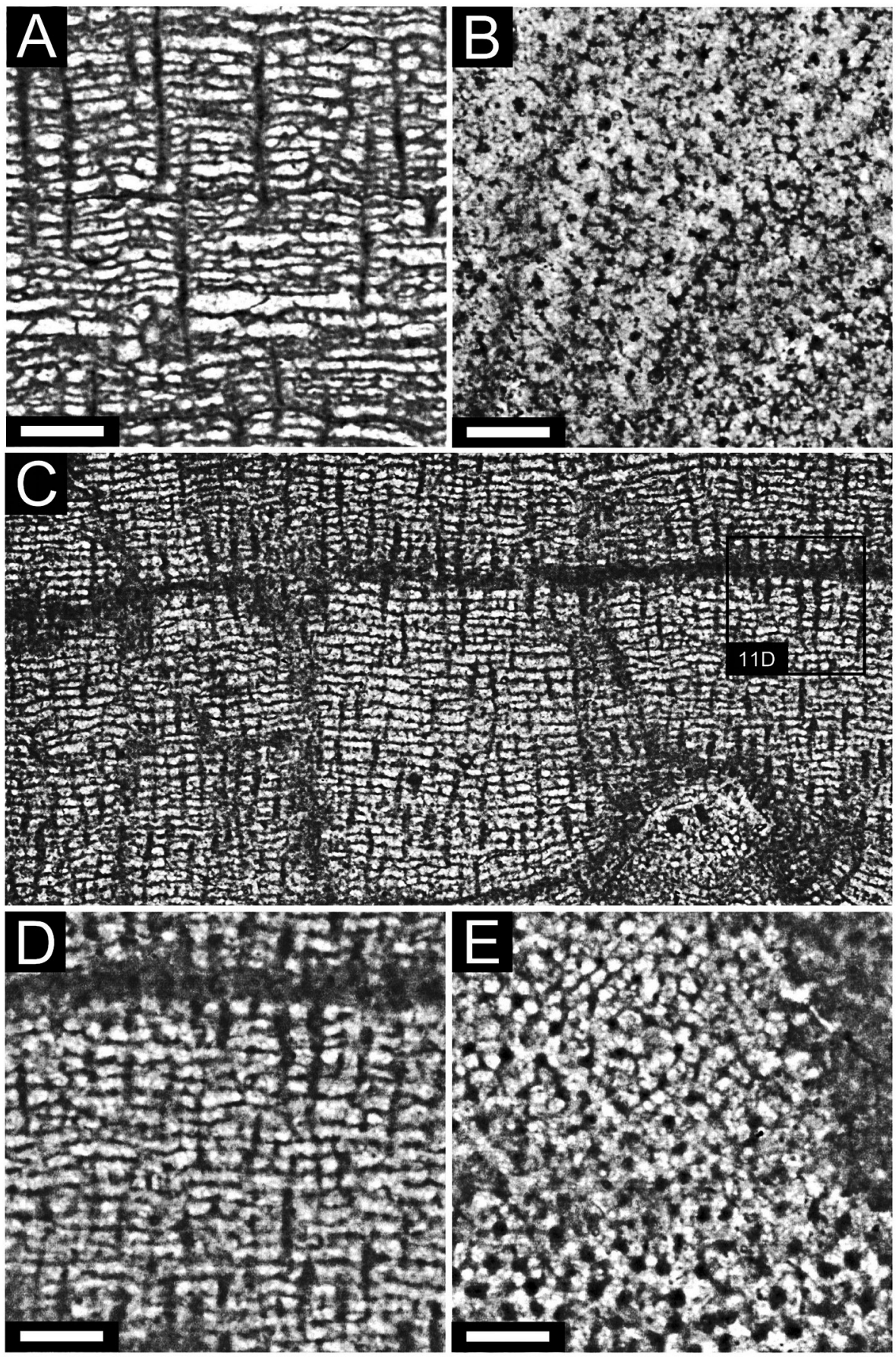

Fig. 11. A-B - Bifariostroma bifarium (Nicholson, 1886a); C-E - Bifariostroma sp. Scale bars equal $1 \mathrm{~mm}$; A - longitudinal thin section of specimen UAM-KOW 24; B - tangential thin section of specimen UAM-KOW 41; C - longitudinal thin section of specimen UAMLGA 18 (width of image: $13 \mathrm{~mm}$ ); D - close-up of the same section; E - tangential thin section of the same specimen.

ed than during the Givetian, which resulted in the emergence of new, more restricted ecological niches, sampled here independently, which could have been occupied by less diversified and more specialised faunas. It is therefore likely that actinostromatids did not undergo any diversity loss during the middle/late Givetian in the study area, following the Taghanic Event of House (2002).

Five (out of nine) species described herein are present in at least three stratigraphical units. Stromatoporoid assemblages are thus relatively uni- form within the carbonate environments of the Devonian of southern Poland, although some distinct patterns can be noted. Species with well-developed colliculi (i.e., A. papillosum, A. stellulatum and A. verrucosum) are common within the middle Givetian undifferentiated Stringocephalus Beds and in the upper Givetian-lower Frasnian coral-stromatoporoid biostromal complex of the Lower Sitkówka Beds, whereas a species with strongly reduced colliculi, poorly visible in tangential sections and not preserved in longitudinal sections (A. cf. A. crassepila- 
Table 3. Percentages of frequency of representatives of the family Actinostromatidae within each lithostratigraphical unit. Only specimens of which thin sections were made are included.

\begin{tabular}{lccc}
\hline \multicolumn{1}{c}{ Section } & $\begin{array}{c}\text { Number of actinostromatids } \\
\text { sampled }\end{array}$ & $\begin{array}{c}\text { Number of massive stro- } \\
\text { matoporoids (laminar } \\
\text { specimens of Stachyodes } \\
\text { excluded) }\end{array}$ & Percentage \\
\hline Wietrznia Beds & 2 & 11 & 18.19 \\
- Wietrznia & 2 & 11 & 18.19 \\
Detrital Beds & 17 & 36 & 47.22 \\
- Grabina & 14 & 32 & 43.75 \\
- Kowala - road cut & 3 & 4 & 75.00 \\
Upper Sitkówka Beds & 19 & 37 & 51.35 \\
- Góra Łgawa & 9 & 14 & 64.28 \\
- Stokówka & 2 & 12 & 16.67 \\
- Zelejowa Góra & 8 & 11 & 72.73 \\
Kadzielnia Member & 6 & 31 & 19.35 \\
- Góra Egawa & 3 & 4 & 75.00 \\
- Kadzielnia & 1 & 6 & 16.67 \\
- Kowala - railroad cut & 2 & 21 & 9.52 \\
Lower Sitkówka Beds & 36 & 91 & 39.56 \\
- Dębnik & 4 & 30 & 13.33 \\
- Góra Łgawa & 2 & 2 & 100.00 \\
\hline - Ołowianka & 17 & 21 & 80.95 \\
- Sowie Górki & 8 & 15 & 53.33 \\
- Stokówka & 5 & 23 & 21.74 \\
Stringocephalus Beds & 14 & 41 & 34.15 \\
- Ołowianka & 4 & 5 & 80.00 \\
- Siewierz & 36 & 27.78 \\
\hline
\end{tabular}

tum), predominated in early Frasnian organic buildups.

Species with poorly developed colliculi are not distinctive, and differences between those species are less clear than in taxa with well-preserved colliculi that are visible in both longitudinal and tangential sections. As a result, the morphological diversity amongst Frasnian actinostromatids from southern Poland is lower than that of Givetian faunas, at least when traditional morphological features are used. The same issue was noted by Stearn (1996) in late Givetian to middle Frasnian Assemblages 7 and 8 in Arctic Canada, where most species of Actinostroma are not distinctive and some of them can be regarded as a different diagenetic expressions of a single species. The validity of stromatoporoid species-level taxonomy was discussed by Stearn (1999) and Kershaw (2013). The general absence of spicules in calcareous skeletons of Palaeozoic stromatoporoid sponges (an exception to this rule having been recorded by Da Silva et al., 2014) makes it difficult to determine whether or not species with a relatively similar calcareous skeleton (e.g., A. crassepilatum, A. densatum, A. filitextum) represent different species of stromatoporoid sponges. Moreover, absence of spicules may mean that stromatoporoids currently classed as Actinostromatidae actually comprise more than one biological family of sponges.

Specimens of Actinostroma stellulatum from the middle Givetian Stringocephalus Beds show poorly aligned colliculi in parts of their skeleton. Colliculi that are not aligned horizontally in the entire skeleton are a diagnostic feature of the genus Plectostro$m a$. This is not known from the Devonian of Poland, but is widely distributed in the Lower Devonian and Eifelian of the Czech Republic (May, 2005). The presence of typical representatives of Plectostroma in the Devonian of Poland cannot be confirmed due to a general paucity of stromatoporoids in pre-Givetian rocks. Specimens described here show aligned colliculi in most of their skeletons; as such, they cannot be ascribed to Plectostroma.

Another pattern that is consistent across the stratigraphical units and environmental settings is the predominance of species with thin, densely spaced pillars and widely spaced laminae (Table 4) in the middle Givetian Stringocephalus Beds. Actinostromatids with long, thick pillars and megapillars (in Bifariostroma) are common in the lower and middle Frasnian. This pattern could reflect either 
Table 4. Skeletal dimensions across lithostratigraphical units; the Wietrznia Beds are omitted on account of the limited number of available data. Median values are supplied for all features. Abbreviations: no. - number of specimens; $x$ - arithmetic mean; $\sigma$ - standard deviation.

\begin{tabular}{|c|c|c|c|c|c|c|c|c|c|c|}
\hline & \multicolumn{2}{|c|}{ Pillar width } & \multicolumn{2}{|c|}{$\begin{array}{l}\text { Thickness } \\
\text { of laminae }\end{array}$} & \multicolumn{2}{|c|}{ Pillar diameter } & \multicolumn{2}{|c|}{$\begin{array}{l}\text { Number of pil- } \\
\text { lars per } 2 \mathrm{~mm}\end{array}$} & \multicolumn{2}{|c|}{$\begin{array}{c}\text { Number of lami- } \\
\text { nae per } 2 \mathrm{~mm}\end{array}$} \\
\hline & $\mathbf{x}$ & $\boldsymbol{\sigma}$ & $\mathbf{x}$ & $\sigma$ & $\mathbf{x}$ & $\boldsymbol{\sigma}$ & $\mathbf{x}$ & $\sigma$ & $\mathbf{x}$ & $\sigma$ \\
\hline \multirow{2}{*}{ Detrital Beds } & 0.63 & 0.26 & 0.06 & 0.01 & 0.25 & 0.06 & 3.75 & 0.47 & 7.59 & 0.94 \\
\hline & \multicolumn{10}{|c|}{ summary: long and thick pillars, wide interlaminar spaces } \\
\hline \multirow{2}{*}{ Kadzielnia Member } & 0.44 & 0.12 & 0.05 & 0 & 0.20 & 0 & 2.75 & 0.35 & 8.75 & 1.27 \\
\hline & \multicolumn{10}{|c|}{ summary: widely-spaced pillars, densely-spaced and thin laminae, short pillars } \\
\hline \multirow{2}{*}{ Lower Sitkówka Beds } & 0.58 & 0.33 & 0.06 & 0.01 & 0.22 & 0.05 & 3.71 & 0.57 & 8.27 & 1.03 \\
\hline & \multicolumn{10}{|c|}{ summary: relatively long pillars } \\
\hline \multirow{2}{*}{ Stringocephalus Beds } & 0.56 & 0.08 & 0.07 & 0.01 & 0.20 & 0.07 & 4.15 & 0.74 & 7.67 & 0.71 \\
\hline & \multicolumn{10}{|c|}{ summary: densely-spaced, thin pillars, relatively thick laminae, wide interlaminar spaces } \\
\hline \multirow{2}{*}{ Upper Sitkówka Beds } & 0.49 & 0.13 & 0.06 & 0.01 & 0.22 & 0.05 & 3.84 & 0.46 & 8.95 & 1.30 \\
\hline & \multicolumn{10}{|c|}{ summary: densely-spaced laminae and pillars } \\
\hline
\end{tabular}

environmental changes on the Devonian shelf or evolutionary changes. Stromatoporoids with rigid and wave-resistant skeletal systems that experienced rapid growth in settings with a high influx of detrital material, could thrive in the high-energy environments documented in the early Frasnian organic buildup that emerged in the Kielce area.

The distribution of morphological variation of skeletal elements across species and palaeoenvironments (Figs. 12-13) also reveals that traditional morphometric features could be influenced by an environmental component of variation, which limits the taxonomic value of those characters. This explains the difficulties in the discrimination of numerous species of Actinostroma, whose diagnoses rely on measurements of quantitative skeletal features. Although some statistical methods in order to establish clear diagnoses of species of Actinostroma have been employed (Flügel, 1959; Cockbain, 1984), the differentiation between less distinctive species remains difficult (Stearn, 1996). For this reason, an alternative set of morphometric features with greater taxonomic potential should be worked out.

Stromatoporoid growth forms differ amongst lithostratigraphical units (Fig. 14) and amongst species (Fig. 15). Tabular actinostromatids are common
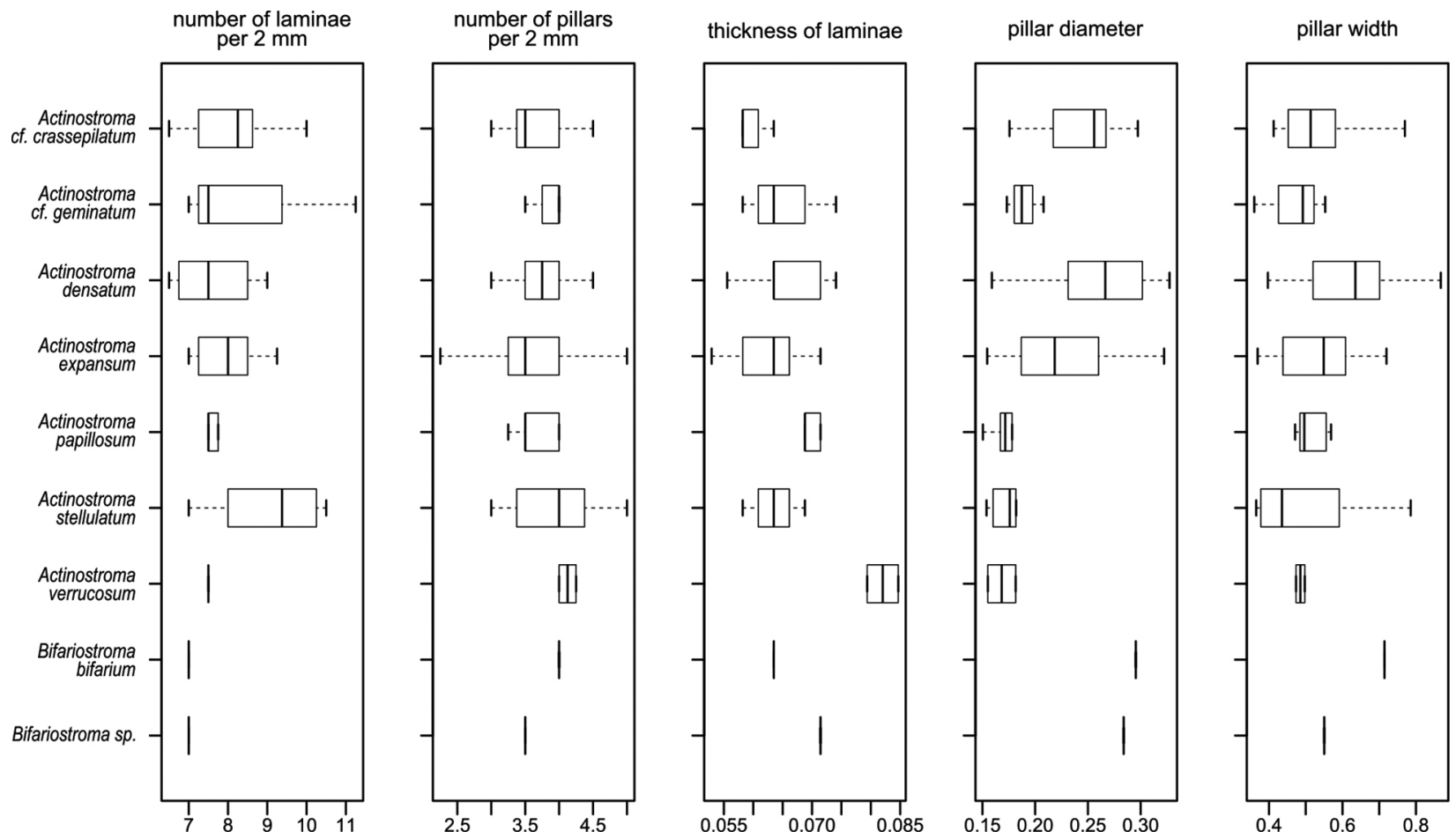

Fig. 12. Distribution of morphological variation amongst species. 

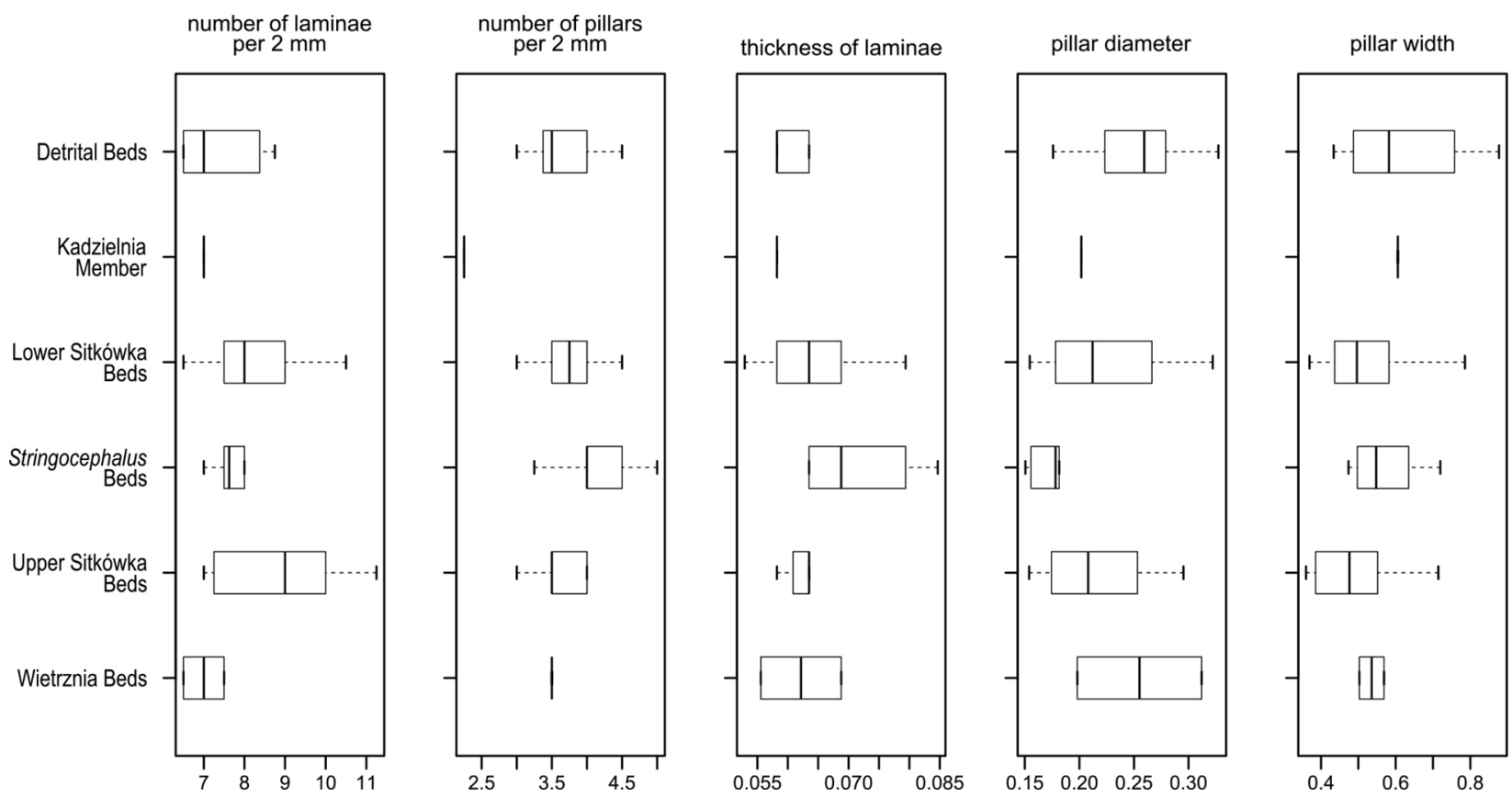

Fig. 13. Distribution of morphological variation across lithostratigraphical units and palaeoenvironments.

in mud mounds of the Kadzielnia Limestone Member and in the biostromal unit of the Stringocephalus Beds. Domical stromatoporoids are numerous in the Lower and Upper Sitkówka Beds, that were laid down in the marginal belt of the shoal, in shallow, agitated waters. Growth form patterns recorded, predominated by tabular and low domical specimens, correspond to the platform interior (sensu

Fig. 14. Distribution of stromatoporoid growth forms across lithostratigraphical units.

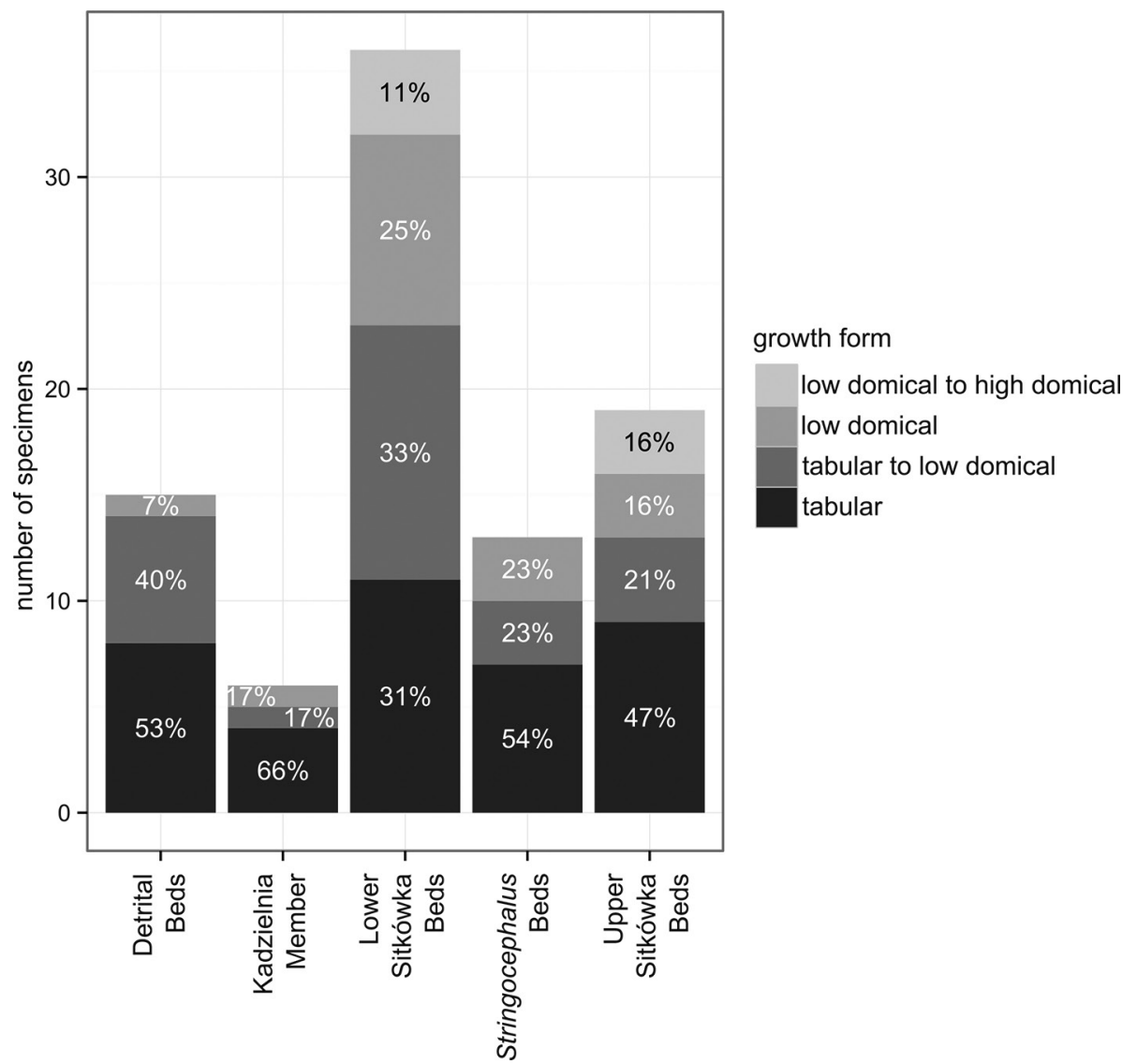




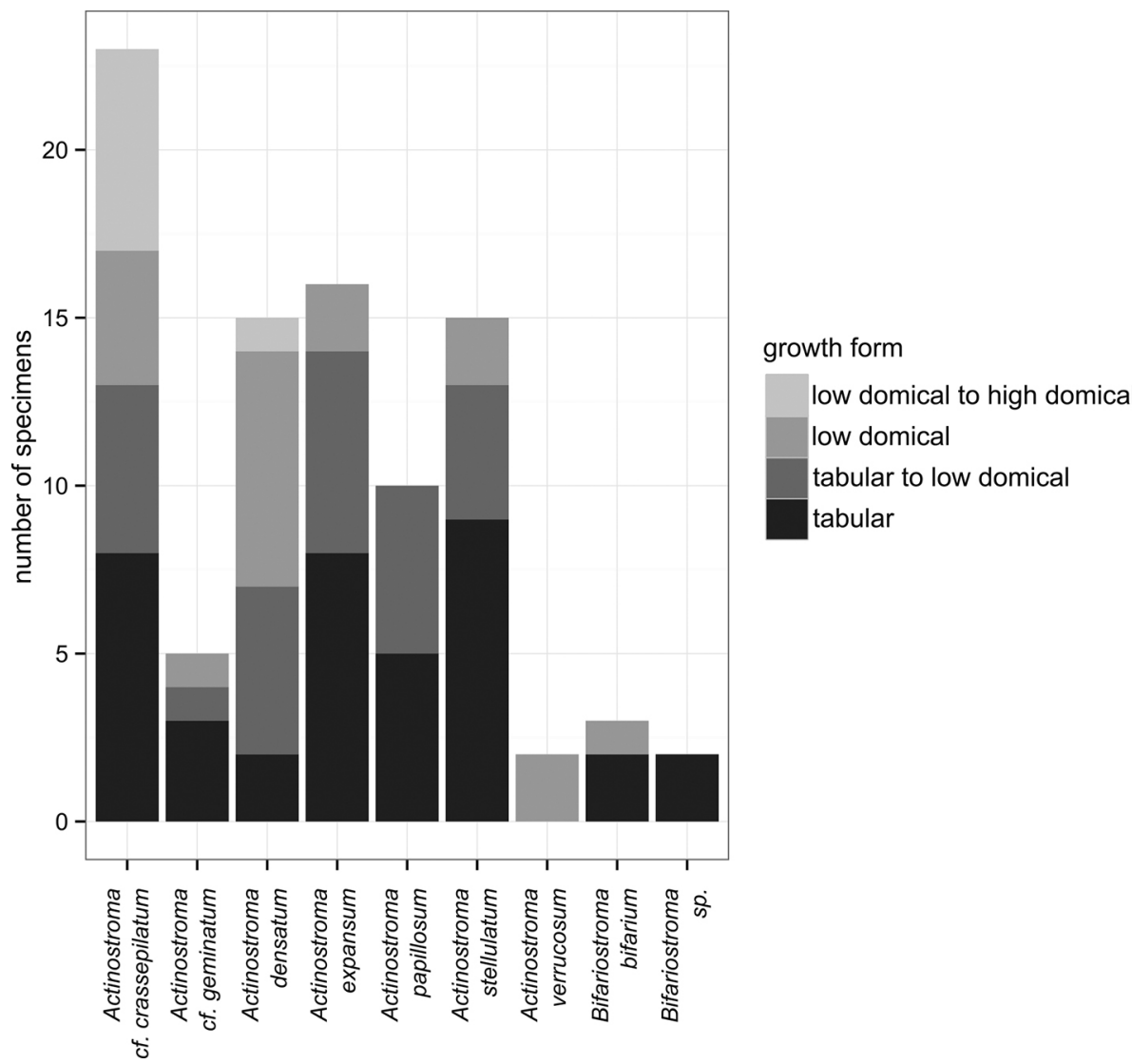

Fig. 15. Distribution of stromatoporoid growth forms amongst species.
Cockbain, 1984) and to the inner zone-inner intermediate zone (sensu Da Silva et al., 2011b), which is consistent with previous palaeoenvironmental interpretations by Racki (1993).

Earlier studies of stromatoporoid shapes in the Frasnian of the Holy Cross Mountains (Łuczyński, 1998, 2008) have shown that the laminar, tabular and low domical growth forms predominate within the Stromatoporoid Detrital Beds (Łuczyński, 2008), which matches the present data. Stromatoporoids from the Upper Sitkówka Beds commonly are high domical to bulbous (Łuczyński, 1998). Such growth forms are rare in the collection described here, in contrast to other localities studied by Łuczyński (1998). However, this difference can be explained by the great environmental variability which is related to recurring storms and rapid sea level oscillations (Łuczyński, 2008). Thus, it is possible that stromatoporoid growth forms may differ within similar palaeoenvironments and carbonate buildup facies.

The distribution of growth forms amongst actinostromatid species (Fig. 15) is less clear and reveals significant intraspecific variation. Actinostroma cf. A. crassepilatum is either tabular to low domical (material from the Detrital Beds) or low to high domical (material from the Lower and Upper Sitkówka Beds). A similar pattern was noted for Actinostroma expansum, with tabular growth forms occurring in the Kadzielnia Member and low domical forms in the Lower Sitkówka Beds. The growth forms of $A$. densatum and $A$. stellulatum are less diversified, with most specimens being low to high domical (A. densatum) and tabular (A. stellulatum). Thus, the present study confirms that stromatoporoid morphology is strongly influenced by palaeoenvironmental conditions. Significant morphological plasticity is common in stromatoporoid sponges; this explains why they can be used as powerful palaeoenvironmental indicators (Kershaw, 1998). However, it must be noted that variations in growth within indistinct species (e.g., A. cf. A. crassepilatum and A. densatum) may be linked to taxonomic inconsistencies at the species level, and not to any response of individual biological species to varying environmental conditions (Kershaw, 2013).

\section{Conclusions}

Representatives of the family Actinostromatidae were important components of the Givetian to Frasnian carbonate bank and organic buildup communities of the Holy Cross Mountains in southern Poland. The genus Actinostroma was commonest 
within the lower Frasnian carbonate buildup margins. The most diverse actinostromatid faunas were found within the middle Givetian Stringocephalus Beds, while species-level biodiversity was lowest within stromatoporoid detrital facies which fringed the Frasnian carbonate buildup.

Species of Actinostroma with well-developed colliculi are commonest in the middle Givetian to lower Frasnian coral-stromatoporoid biostromal complexes, whereas the species with strongly reduced colliculi predominate the lower-middle Frasnian organic buildups. Differences between the latter species are less pronounced, which may be caused by the lesser morphological diversity of Frasnian stromatoporoids or by taxonomic inconsistencies at the species level. Actinostromatids with poorly developed colliculi and long, thick pillars had rigid and wave-resistant skeletal systems, and could thrive in the high-energy settings represented by the early Frasnian organic buildup in the Kielce area (southern Poland).

Stromatoporoid shapes differ among species and palaeoenvironments. The distribution of growth forms amongst species reveals a significant intraspecific variation. Actinostroma cf. A. crassepilatum and Actinostroma expansum can be either tabular or low domical, depending on the palaeoenvironmental setting. Thus, the present study confirms that environmental conditions had a strong impact on stromatoporoid morphology.

The distribution of growth forms amongst palaeoenvironmental settings shows a more uniform pattern. Tabular actinostromatids are common in the biostromal unit of the undifferentiated Stringocephalus Beds and in the lower Frasnian mud mounds. Domical stromatoporoids were numerous in the marginal belt of the shoal, inhabiting shallow, agitated waters. Growth form patterns recorded, with a predominance of tabular and low domical specimens, correspond to a platform interior (sensu Cockbain, 1984) and an inner zone-inner intermediate zone (sensu Da Silva et al., 2011b).

\section{Acknowledgements}

I am grateful to M. Coen-Aubert, A. Folie and E. Steurbaut (Royal Belgian Institute of Natural Sciences, Brussels, Belgium) and J. Kaźmierczak (Polish Academy of Sciences, Warsaw, Poland) for providing access to collections in their care. An earlier version of the typescript benefited from insightful comments by Carl W. Stock.

\section{References}

Bargatzky, A., 1881. Die Stromatoporen des rheinischen Devons. Verhandlungen des Naturhistorischen Vereins der Preussischen Rheinlande und Westfalen 38, 233-304.

Cockbain, A.E., 1984. Stromatoporoids from the Devonian reef complexes, Canning Basin, Western Australia. Geological Survey of Western Australia Bulletin 129, $1-108$.

Cook, A.G., 1999. Stromatoporoid palaeoecology and systematics from the Middle Devonian Fanning River Group, north Queensland. Memoirs of the Queensland Museum 43, 463-551.

Da Silva, A.-C., Kershaw, S. \& Boulvain, F., 2011a. Sedimentology and stromatoporoid palaeoecology of Frasnian (Upper Devonian) carbonate mounds in southern Belgium. Lethaia 44, 255-274.

Da Silva, A.-C., Kershaw, S. \& Boulvain, F., 2011b. Stromatoporoid palaeoecology in the Frasnian (Upper Devonian) Belgian platform, and its applications in interpretation of carbonate platform environments. Palaeontology 54, 883-905.

Da Silva, A.-C., Kershaw, S., Boulvain, F., Hubert, B.L.M., Mistiaen, B., Reynolds, A. \& Reitner, J., 2014. Indigenous demosponge spicules in a Late Devonian stromatoporoid basal skeleton from the Frasnian of Belgium. Lethaia 47, 365-375.

Flügel, E., 1956. Revision der Hydrozoen des Grazer Devons. Mitteilungen der Geologischen Gesellschaft in Wien 49, 129-172.

Flügel, E., 1959. Die Gattung Actinostroma Nicholson und ihre Arten (Stromatoporoidea). Annalen des Naturhistorischen Museums Wien 63, 190-273.

Goldfuss, G.A., 1826. Petrefacta Germaniae. I. Arnz and Company, Düsseldorf, 252 pp.

Hall, J. \& Whitfield, R.P., 1873. Descriptions of new species of fossils from the Devonian rocks of Iowa. New York State Cabinet of Natural History Annual Report 23, 223-239.

House, M.R., 2002. Strength, timing, setting and cause of mid-Palaeozoic extinctions. Palaeogeography, Palaeoclimatology, Palaeoecology 181, 5-25.

Kaźmierczak, J., 1971. Morphogenesis and systematics of the Devonian Stromatoporoidea from the Holy Cross Mountains, Poland. Palaeontologia Polonica 26, 1-150.

Kershaw, S., 1998. The applications of stromatoporoid palaeobiology in palaeoenvironmental analysis. Palaeontology 41, 509-544.

Kershaw, S., 2013. Palaeozoic stromatoporoid futures: A discussion of their taxonomy, mineralogy and applications in palaeoecology and palaeoenvironmental analysis. Journal of Palaeogeography 2, 163-182.

Khalfina, V.K., 1968. O novykh rodakh stromatoporoideř iz dewonskikh otlozheniĭ IUZ okrainy Kuzbassa i Altaia [On some new genera of stromatoporoids from the Devonian of the south-eastern margin of the Kuznetsk Basin and Altai]. Trudy Tomskogo Gosudarstvennogo Universiteta, Seriia Geologicheskaia 202, 147-152.

Khalfina, V.K., 1972. Stromatoporoider [Stromatoporoids]. [In:] B.S. Sokolov, A.B. Ivanovskii \& E.V. Kras- 
nov (Eds): Morphology and Terminology of the Coelenterates. Akademiâ Nauk SSSR, Sibirskoe Otdelenie, Trudy Instituta Geologii i Geofiziki 133, 148-152.

Kowalczewski, Z., 1963. Transwersalne założenia $\mathrm{w}$ budowie cokołu paleozoicznego antyklinorium świętokrzyskiego [Transversal foundations in geological structure of Palaeozoic socle of the Święty Krzyż Anticlinorium]. Geological Quarterly 7, 571-586.

Krawczyński, W., 2002. Frasnian gastropod synecology and bio-events in the Dyminy reef complex of the Holy Cross Mountains, Poland. Acta Palaeontologica Polonica 47, 267-288.

Krebedünkel, J., 1995. Stromatoporen aus dem Givet und Frasne des Bergischen Landes. Geologischen Instituts der Universität zu Köln, Sonderveröffentlichungen 106, 1-182.

Lecompte, M.J., 1951. Les stromatoporoïdes du Dévonien moyen et supérieur du Bassin de Dinant. Institut Royal des Sciences Naturelles de Belgique, Mémoire 116, 1-218.

Łaptaś, A., 1982. Sedymentacja utworów węglanowych dewonu środkowego rejonu Dębnika [Sedimentation of the Middle Devonian carbonates of the Dębnik area]. Studia Geologica Polonica 75, 59-100.

Łuczyński, P., 1998. Stromatoporoid morphology in the Devonian of the Holy Cross Mountains, Poland. Acta Palaeontologica Polonica 43, 653-663.

Łuczyński, P., 2008. Growth forms and distribution patterns of stromatoporoids exposed on Devonian palaeobottom surfaces; Holy Cross Mountains, central Poland. Acta Geologica Polonica 58, 303-320.

May, A., 2005. Die Stromatoporen des Devons und Silurs von Zentral-Böhmen (Tschechische Republik) und ihre Kommensalen. Zitteliana B25, 1-134.

Mistiaen, B., 1980. Stromatopores du Givétien de Ferques (Boulonnais, France). Bulletin du Musee Nationale d'Histoires Naturelles 4, 2C, 167-257.

Mistiaen, B., 1988. Stromatopores du Givétien et du Frasnien de Ferques (Boulonnais - France). [In:] D. Brice (Ed.): Le Dévonien de Ferques: Bas-Boulonnais (N. France). Collection Biostratigraphie du Paléozoïque 7, 163-195.

Narkiewicz, M. \& Racki, G., 1984. Stratygrafia dewonu antykliny Dębnika [Stratigraphy of the Devonian of the Dębnik anticline]. Geological Quarterly 28, 513-546.

Narkiewicz, M., Racki, G \& Wrzołek, T., 1990. Litostratygrafia dewońskiej serii stromatoporoidowo-koralowcowej w Górach Świętokrzyskich [Lithostratigraphy of the Devonian stromatoporoid-coral carbonate sequence in the Holy Cross Mountains]. Geological Quarterly 34, 433-456.

Nestor, H.E., 1964. Stromatoporoidei Ordowika i Llandoweri Estonii [Stromatoporoids from the Ordovician and Llandovery of Estonia]. Akademiia Nauk Estonskoi SSR, Tallin, 112 pp.

Nicholson, H.A., 1886a. On some new or imperfectly-known species of stromatoporoids. Annals and Magazine of Natural History, Series 517, 225-239.

Nicholson, H.A., 1886b. A monograph of the British stromatoporoids. Pt 1. Monograph of the Palaeontographical Society 39, 1-130.
Pisarzowska, A., Sobstel, M. \& Racki, G., 2006. Conodont-based event stratigraphy of the Early-Middle Frasnian transition on the South Polish carbonate shelf. Acta Palaeontologica Polonica 51, 609-646.

Racki, G., 1993. Evolution of the bank to reef complex in the Devonian of the Holy Cross Mountains. Acta Palaeontologica Polonica 37, 87-182.

Racki, G. \& Sobstel, M., 2004. Very large stromatoporoid indicating Early Frasnian reef core (Holy Cross Mts., Poland). Geological Quarterly 48, 83-88.

Salerno, C., 2008. Stromatoporen-Fauna, Fazies und Paläoökologie von Plattformkarbonaten aus dem Unter-Givetium der Eifel (Devon, Rheinisches Schiefergebirge). Zitteliana B27, 1-129.

Sobstel, M., 2003. Sedimentary record of eustatic changes on the Givetian (Devonian) carbonate platform of Małopolska Massif, southern Poland. Acta Geologica Polonica 53, 189-200.

Stearn, C.W., 1996. Stromatoporoids from the Devonian (Eifelian to lowest Frasnian) of Manitoba, Canada. Journal of Paleontology 70, 196-217.

Stearn, C.W., 1999. Easy access to doubtful taxonomic decisions. Palaeontologia Electronica 2, 4 pp.

Stearn, C.W., Webby, B.D., Nestor, H. \& Stock, C.W., 1999. Revised classification and terminology of Palaeozoic stromatoporoids. Acta Palaeontologica Polonica $44,1-70$.

Stock, C.W., 1984. Upper Devonian (Frasnian) Stromatoporoidea of north-central Iowa: redescription of the type specimens of Hall and Whitfield (1873). Journal of Paleontology 58, 773-788.

Stock, C.W. \& Burry-Stock, J.A., 1998. Two new genera of Upper Silurian actinostromatid stromatoporoids. Journal of Paleontology 72, 190-201.

Stock, C.W., 2012. Actinostromatida. [In:] P.A. Selden (Ed.): Treatise Online. Pt. E (Revised). Porifera. Geological Society of America and University of Kansas Press, Lawrence, 1-12.

Szulczewski, M., 1971. Upper Devonian conodonts, stratigraphy and facial development in the Holy Cross Mts. Acta Geologica Polonica 21, 1-129.

Szulczewski, M., 1995. Depositional evolution of the Holy Cross Mts. (Poland) in the Devonian and Carboniferous - a review. Geological Quarterly 39, 449-542.

Wolniewicz, P., 2010. Stromatoporoid biometrics using image analysis software: a first order approach. Computers and Geosciences 36, 550-558.

Wood, R., 2000. Palaeoecology of a Late Devonian back reef: Canning Basin, Western Australia. Palaeontology 43, 671-703.

Wray, J.L., 1967. Upper Devonian calcareous algae from the Canning Basin, western Australia. Colorado School of Mines 3, 76 pp.

Zukalová, V., 1981. Stromatoporoids in the Devonian carbonate complex in Moravia (Czechoslovakia). Acta Palaeontologica Polonica 25, 671-679.

Manuscript received: 27 June 2016 Revision accepted: 20 September 2016 


\section{Appendix 1. Register of localities}

Dębnik (abbreviated DEB; 5009N, 1940'E). A small inactive quarry north of the village of Dębnik near Kraków. Łaptaś (1982) called this outcrop "new quarry". Genus Actinostroma was sampled from the lowermost part of the profile, in the eastern part of the quarry. For a profile see Łaptaś (1982). For details on the stratigraphy of the Dębnik area see Narkiewicz and Racki (1984). Upper Givetian.

Góra Łgawa (LGA; 5047'N, 20³0’E). Small pits and natural exposures east of the active Jaźwica quarry. Lower Sitkówka Beds, Kadzielnia Limestone Member, Upper Sitkówka Beds (sets G-K in Racki, 1993). Upper Givetian to lower Frasnian.

Góra Sołtysia (SOL; 5047’ N, 20³2’E). Lower Sitkówka Beds, set C in Racki (1993). Upper Givetian. Specimens of Actinostroma from the collection of Kaźmierczak (1971) were investigated.

Grabina (GRA; 5052'N, 20³4'E). Stromatoporoids were sampled from sets B and C (Upper Sitkówka Beds to Detrital Beds; middle to upper Frasnian; Racki, 1993). For detailed profile, see Krawczyński (2002).

Kadzielnia (KDZ; 5051'N, 20³7'E). Samples from the collection of Maria Różkowska, housed at the Institute of Geology, Adam Mickiewicz University, Poznań, Poland, were used. Kadzielnia Limestone Member, set A in Racki (1993). Lower Frasnian.

Kowala - railroad cut (KOW; 5047'N, 20³3'E). Kadzielnia Limestone Member, set C. For de- tailed profile, see Szulczewski (1971) and Pisarzowska et al. (2006). Lower Frasnian.

Kowala - road cut (KOD; 5047’ N, 20³3’E). Detrital Beds. Upper Frasnian.

Ołowianka (OLO and OLOSTR; 5050’ N 20²2'E). Genus Actinostroma was sampled from the most northwestern part of the quarry (Stringocephalus Beds, set B in Racki, 1993) and from the western part of the quarry (Lower Sitkówka Beds, sets D-E). Middle to upper Givetian.

Siewierz (Dziewki; DZI; 50³0’N, 19¹1'E). Small pits between the villages of Brudzowice and Dziewki located in the northeastern part of Upper Silesia. Set C in Racki (1993), equivalent of the Stringocephalus Beds. For a profile see Racki (1993). Givetian.

Sitkówka-Kostrzewa (SIT; 5049’N, 20³3’E). Lower Sitkówka Beds, set C in Racki (1993). Earliest Frasnian. Specimens of Actinostroma from the collection of Kaźmierczak (1971) were investigated.

Sowie Górki (SOG; 5050'N, 20²2'E). Lower Sitkówka Beds, set D in Racki (1993). Upper Givetian.

Stokówka (STO; 5049’ N, 20²5’E). Lower Sitkówka Beds (set F in Racki, 1993) and Upper Sitkówka Beds (set G). For a detailed profile, see Racki (1993). Upper Givetian to lower Frasnian.

Wietrznia (WIE; 5051'N, 20³8' E). Wietrznia Beds (set D in Pisarzowska et al., 2006). Middle Frasnian.

Zelejowa Góra (ZEL; 5049’ N, 20²7’ E). Upper Sitkówka Beds. Lower Frasnian. 